\title{
SELECTED DOCUMENTS RELATING TO THE "SEPTEMBER 30TH MOVEMENT" AND ITS EPILOGUE
}

EDITORIAL NOTE: The editors wish to acknowledge from the outset that the collection of documents appended below is very far from providing a comprehensive coverage of the roles of the various important groups and individuals affected by, or involved in the events of October 1, 1965. But we are confident that this collection constitutes a reasonably representative sample of the positions taken publicly by the political elements most directly concerned.

Priority has been given to material which has for one reason or another not yet been made readily accessible to students of Indonesian affairs. The chief criterion of selection has been, however, direct relevance to the actual events of October 1 and 2 , in Djakarta and the regions most deeply affected. Each document is prefaced by a brief editorial comment noting the time and place of issuance - where this is known. An attempt is also made - where necessary - to suggest the significance of some selections.

\section{INDEX OF DOCUMENTS}

I. STATEMENTS OF THE SEPTEMBER 30th MOVEMENT.

1. Initial Statement of Lieutenant Colonel Untung.

2. Decree No. I on the Establishment of the Indonesian Revolution Council.

3. Decision No. 1 Concerning the Composition of the Indonesian Revolution Council.

4. Decision No. 2 Concerning Demotion and Promotion in Rank.

5. Affiliations of Indonesian Revolution Council Members [compiled by the editors].

II. STATEMENTS OF THL IIIDONESIAN AIR FORCE.

1. Air Force Commander Dani's Order of the Day (October 1).

2. Air Force Commander Dani's Statement in Jogjakarta (October 2).

3. Deputy Air Force Commander Andoko's Statement (October 2).

4. Air Force Commander Dani's Statement at Halim Air Base (October 2).

5. Statement of the Seventh Regional Air Command, Central Java (October 2).

6. Statement of the Commander of the Panasan (Surakarta) Air Force Base (October 3). 
III. STATEMENTS OF PRESIDENT SUKARNO AND THE TJAKRABIRAWA REGIMENT.

1. Announcement of the Commander of the Tjakrabirawa Regiment (October 1).

2. President Sukarno's Order of the Day Appointing Major General Pranoto as Caretaker of the Army (October I).

3. Announcement of the Commander of the Tjakrabirawa Regiment (October 2).

4. President Sukarno's First Message Following the Collapse of the September 30th Movement (October 3).

5. President Sukarno's Second Message (October 3).

6. President Sukarno's First Press Interview Following the Collapse of the September 30 th Movement (October 14).

7. Comments of the Tjakrabirawa Regiment Leadership on the Events of October 1 (October 14).

IV. STATEMENTS OF THE INDONESIAN ARMY LEADERSHIP.

1. First Army Broadcast After Recovering Control of the Djakarta Radio (October 1).

2. Army Commander Suharto's Statement upon Discovery of the Bodies of the Murdered Generals (October 4).

3. Speech by Army Commander Suharto to Central and Regional Leaders of the National Front (October 15).

4. Speech by Colonel Widodo, Caretaker Commander of the 72nd Military Resort (October 7?).

5. Statement of Defense Minister General A. H. Nasution on the Origins of the September 30th Movement (November 12).

V. STATEMENTS OF THE INDONESIAN COMMUNIST PARTY (P.K.I.).

1. Editorial in Harian Rakjat (October 2).

2. Statement of the Leadership of the East Java Pemuda Rakjat (October 1).

3. Statement of the North Sumatra Committee of the P.K.I. (October 4).

4. Statement of the Jogjakarta Regional Committee of the P.K.I. (October 5).

5. Statement of the Political Bureau of the Central Committee of the P.K.I. (October 5).

6. Appeal of the Central Java Committee of the P.K.I. (October 7 or 8 ).

7. Policy Guide-Line Issued by the Acting Governor of Central Java, Sujono Atmo (mid-October).

8. Interview of Second Deputy Chairman of the P.K.I. Njoto with Asahi Shimbun (December 2). 
VI. STATEMENTS OF THE INDONESIAN NATIONALIST PARTY (P.N.I.).

1. General Statement of the Central Leadership Council of the P.N.I. (October 1).

2. Statement of the Central Leadership Council of the Marhaenist Mass Movement (October 1?).

3. Press Statement of the Central Leadership Council of the P.N.I. on the Inclusion of Some of its Members in the Indonesian Revolution Council (October 1 ).

VII. STATEMENT OF THE N.U., P.S.I.I., I.P.K.I. AND CATHOLIC PARTY.

1. Statement of the N.U., P.S.I.I., I.P.K.I. and the Catholic Party (October 4). 


\section{STATEMENTS OF THE SEPTEMBER 30 th MOVEMENT.}

[All translations are based on Indonesian texts found in Antara (Warta Berita), October 1 (afternoon edition) and Harian Rakjat, October 2.]

1. Initial Statement of Lieutenant Colonel Untung (Text as broadcast over the Djakarta radio at approximately $7: 15$ a.m. on the morning of October 1.)

On Thursday, September 30,1965 , a military move took place within the Army in the capital city of Djakarta which was aided by troops from other branches of the Armed Forces. The September 30th Movement, which is led by Lieutenant Colonel Untung, Commandant of a Battalion of the Tjakrabirawa, the personal bodyguard of President Sukarno, is directed against Generals who were members of the self-styled Council of Generals. A number of Generals have been arrested and important communications media and other vital installations have been placed under the control of the September 30th Movement, while President Sukarno is safe under its protection. Also a number of other prominent leaders in society, who had become targets of the action by the Council of Generals, are under the protection of the September 30th Movement.

The Council of Generals is a subversive movement sponsored by the CIA and has been very active lately, especially since President Sukarno was seriously ill in the first week of August of this year. Their hope that President Sukarno would die of his illness has not materialized.

Therefore, in order to attain its goal the Council of Generals had planned to conduct a show of force (machtvertoon) on Armed Forces Day, October 5 this year, by bringing troops from East, Central and West Java. With this large concentration of military power the Council of Generals had even planned to carry out a counter-revolutionary coup prior to October 5, 1965. It was to prevent such a counter-revolutionary coup that Lieutenant Colonel Untung launched the September 30th Movement which has proved a great success.

According to a statement obtained from Lieutenant Colonel Untung, the Commandant of the September 30th Movement, this movement is solely a movement within the Army directed against the Council of Generals which has stained the name of the Army and harbored evil designs against the Republic of Indonesia and President Sukarno. Lieutenant Colonel Untung personally considers this movement as an obligation for him as a member of the Tjakrabirawa which has the duty to protect the President and the Republic of Indonesia.

The Commandant of the September 30th Movement further explained that the action already taken against the Council of Generals in Djakarta will be followed by actions throughout Indonesia against agents and sympathizers of the Council of Generals in the regions. According to the statement of the Commandant of the September 30th Movement, as a follow-up action, an 
Indonesian Revolution Council will be established in the capital, while in the regions Provincial, District, Sub-District, and Village Revolution Councils will be established. Members of the Revolution Council will be composed of civilians and military personnel who fully support the September 30th Movement.

Political parties, mass organizations, newspapers, and periodicals may continue functioning, provided that within a time period which will be specified later they declare their loyalty to the Indonesian Revolution Council.

The Indonesian Revolution Council which will be established by the September 30 th Movement will consistently carry out the Pantia Azimat Revolusi $(*)$, the decisions of the MPRS, the decisions of the DPR-GR, and the decisions of the DPA. The Indonesian Revolution Council will not change the Indonesian foreign policy, which is free and active and antinekolim, for the sake of peace in Southeast Asia and in the world. Also there will be no change of policy with regard to the Second Afro-Asian Conference and Conefo, as well as the confrontation against Malaysia; and KIAPMA, along with other international activities which have been scheduled to take place in Indonesia, will be held as planned.

As Commandant of the September 30th Movement, Lt. Colone1 Untung called on the entire Indonesian people to continue to increase vigilance and fully assist the September 30th Movement in order to safeguard the Indonesian Republic from the wicked deeds of the Council of Generals and its agents, so that the Message of the People's Suffering can be fulfilled in the true sense of the word.

Lt. Colonel Untung appealed to all Army officers, non-commissioned officers and soldiers to be resolute and to act to eradicate completely the influence of the Council of Generals and its agents in the Army. Power-mad. Generals and officers who have neglected the lot of their men and who above the accumulated sufferings of their men have lived in luxury, led a gay life, insulted our women and wasted government funds, must be kicked out of the Army and punished accordingly. The Army is not for generals, but is the possession of all the soldiers of the Army who are loyal to the ideals of the revolution of August 1945. Lt. Colonel Untung thanked all troops of the Armed Forces outside the Army for their assistance in the purging of the Army and hoped that purges also will be carried out in the other branches of the Armed Forces against agents and sympathizers of the Council of Generals. Within a short time Commandant Lt. Colonel Untung will announce the First Decree concerning the Indonesian Revolution Council; other decrees will follow.

Djakarta, September 30, 1965. Information Section of the September 30 th Movement, as broadcast over the Indonesian Radio in Djakarta.

* The "Pantja Azimat Revolusi" translates imperfectly as "the five charms of the Revolution". As designated by President Sukarno in June 1965, these are the following Indonesian ideological concepts: Nasakom; Pantjasila; the Political Manifesto; Trisakt;; and Berdikari. See Sukarno's Independence Day Speech on August 17, 1965, in Antara, August $17,1965$. 
2. "Decree No. 1 on the Establishment of the Indonesian Revolution Council" (Text as read over the Djakarta radio at approximate1y 2:00 p.m., October 1.)

(Text) In the interest of the State of the Indonesian Republic, in the interest of safeguarding the implementation of the Pantiasila and the Pantia Azimat Revolusi completely, in the interest of the safety of the Army and of the Armed Forces in general, at midnight Thursday, September 30, 1965, a purge was carried out in the Capital City of the Republic of Indonesia, Djakarta, against members of the self-styled Council of Generals which had planned a coup on the eve of Armed Forces Day, October 5, 1965.

A number of Generals have been arrested. Means of communications and other vital installations in the capital have fallen completely under the control of the September 30th Movement.

The September 30th Movement is a movement entirely confined within the body of the Army to put an end to arbitrary actions of Generals who were members of the Council of Generals and other Officers who were henchmen and sympathizers of members of the Council of Generals. This movement was assisted by Armed Units not belonging to the Army.

2. To facilitate the follow-up of the action of September 30,1965 , the leadership of the September 30th Movement will set up an Indonesian Revolution Council whose members will consist of civilian and military individuals who unreservedly support the September 30th Movement.

For the time being, pending general elections for the People's Consultative Council (Madjelis Permusjawaratan Rakjat) in line with the Constitution of 1945, the Indonesian Revolution Council will constitute the source of all authority in the Republic of Indonesia. The Indonesian Revolution Council is a tool of the entire Indonesian people to realize the Pantjasila and the Pantja Azimat Revolusi completely.

The Indonesian Revolution Council in its daily activities will be represented by a Presidium of the Council which will consist of the Commandant and Deputy Commandants of the September 30th Movement.

3. With the falling of the entire authority of the State into the hands of the Indonesian Revolution Council, the Dwikora Cabinet automatically assumes a decommissioned status. Until the formation of a new Council of Ministers by the Indonesian Revolution Council, former ministers are dutybound to carry out routine tasks, and to preserve order in their respective departments. They are prohibited from appointing new employees and from taking actions which may have broad consequences. All former ministers are obliged to give a full account to the Indonesian Revolution Council, along with the new ministers to be appointed by the Indonesian Revolution Council.

4. As instruments of the Indonesian Revolution Council, there are to be established in the regions, Provincial Revolution Councils (with a maximum membership of 25), District Revolution Councils (with a maximum membership of 15), Subdistrict Revolution Councils (with a maximum membership of 
10), and Village Revolution Councils (with a maximum membership of 7). They are to be composed of civilian and military personnel who unreservedly support the September 30th Movement.

These Regional Revolution Councils constitute the highest authority in the regions concerned. At the provincial and district levels they are assisted in their work by the respective Bodies for Day to Day Administration (BPH), while at the subdistrict and village levels they are assisted by the local National Front Leadership composed of individuals who unreservedly support the September 30th Movement.

5. The Presidium of the Indonesian Revolution Council consists of the Commandant and Deputy Commandants of the September 30th Movement. The Commandant and Deputy Commandants of the September 30th Movement are Chairman and Vice Chairmen of the Indonesian Revolution Council.

6. Immediately after the establishment of Regional Revolution Councils the Revolution Council Chairman concerned must report to the Revolution Council one level higher concerning the full composition of the Council membership. Provincial Revolution Councils must acquire written approval from the Presidium of the Indonesian Revolution Council. District Revolution Councils must acquire written approval from the Provincial Revolution Councils and the Subdistrict and Village Revolution Councils must acquire written approval from the District Revolution Councils.

Djakarta, October 1, 1965. Command of the September 30th Movement. Commandant: Lieutenant Colone1 Untung. Deputy Commandant: Brigadier General Supardjo; Deputy Commandant: Flight Lieutenant Colonel Heru; Deputy Commandant: Sea Colonel Sunardi; Deputy Commandant: Adjunct Senior Police Commissioner Anwas. Announced by the Information Section of the September 30th Movement on October 1, 1965.

3. "Decision No. 1 Concerning the Composition of the Indonesian Revolution Council"

(Text as read over the Djakarta Radio at approximately 2:05 p.m.,October 1.)

I. Fulfilling the provisions of Decree No. 1 concerning the Formation of The Indonesian Revolution Council, herewith follows the full membership of the Indonesian Revolution Council:

1. Lieutenant Colonel UNTUNG, Chairman of the Council.

2. Brigadier General SUPARDJO, Vice-Chairman of the Council.

3. Flight Lieutenant Colonel HERU, Vice-Chairman of the Council.

4. Sea Colonel SUNARDI, Vice-Chairman of the Council.

5. Adjunct Senior Police Commissioner ANWAS, Vice-Chairman of the Council.

6. OMAR DHANI, Air Vice Marshal.

7. SUTJIPTO JUDODIHARDJO, Police Inspector General.

8. E. MARTADINATA, Vice Admiral.

9. DR. SUBANDRIO.

10. DR. J. LEIMENA.

11. IR. SURACHMAN (Nationalist Group). 
12. FATAH JASIN (Religious Group).

13. K. H. SIRADJUDDIN ABBAS (Religious Group).

14. TJUGITO (Conmunist Group).

15. ARUDJI KARTAWINATA.

16. SIAUW GIOK TJHAN.

17. SUMARNO S. H.

18. HARTONO, Major General, Navy Marine Corps.

19. SUTARTO, Police Brigadier General.

20. ZAINI MANSUR (Central Youth Front).

21. JAHJA S. H. (Central Youth Front).

22. SUKATNO (Central Youth Front).

23. BAMBANG KUSNOHADI (PPMI).

24. ABDUL RAHMAN (Deputy Secretary General of the National Front).

25. HARDOJO (University Student).

26. BASUKI RACHMAT, Major General.

27. RYACUDU, Brigadier General.

28. SOLICHIN, Brigadier General.

29. AMIR MAHMUD, Brigadier General.

30. ANDI RIVAI, Brigadier General.

31. SUJONO, Flight Major.

32. LEO WATTIMENA, Air Commodore.

33. MRS. UTAMI SURJADARMA.

34. A. IATIEF, Colone1.

35. UMAR WIRAHADIKUSUMAH, Major General.

36. MRS. SUPENI.

37. MRS. MAFMUDAH MAWARDI.

38. MRS. SUHARTI SUWARTO.

39. FATAH, Colone1.

40. SUHERMAN, Colonel.

41. SAMSU SUTJIPTO, Sea Colonel.

42. SUHARDI (Journalist).

43. DRS. SUMARTONO, Senior Police Commissioner.

44. DJUNTA SUWARDI.

45. KARIM D. P. (Indonesian Journalists Association).

II. The Chairman and the Vice-Chairmen of the Council constitute the Presidium of the Indonesian Revolution Council which between two plenary sessions of the Council acts on behalf of the Council.

III. All civilian members of the Indonesian Revolution Council are given the right to use the military insignia of Lieutenant Colone 1 or equivalent rank. Indonesian Revolution Council members from the Armed Forces group maintain their previous ranks with the exception that those higher than Lieutenant Colonel must use the same ranks as that of the Commandant of the September 30th Movement, namely that of Lieutenant Colonel or the equivalent.

COMMAND OF THE SEPTEMBER 30th MOVEMENT

Chairman of the Indonesian Revolution Council Signed

(Lieutenant Colonel Untung)

DJAKARTA, October 1, 1965. Announced by the Information Section of the September 30th Movement on October 1, 1965. 
4. "Decision No. 2 concerning Demotion and Promotion in Rank" (Text as read over the Djakarta radio at approximately $2: 10 \mathrm{p} . \mathrm{m}_{\text {。 }}$ on October 1.)

1. As all authority in the State of the Republic of Indonesia on September 30, 1965, was taken over by the September 30th Movement and as its Conmandant is an Officer with the rank of Lieutenant Colonel, all ranks and equivalent grades in the Armed Forces of the Republic of Indonesia above that of Lieutenant Colonel are herewith declared invalid.

All officers who were previously of a rank higher than Lieutenant Colonel must state their loyalty in written form to the Indonesian Revolution Council and only thereafter have they the right to use the rank of Lieutenant Colonel. Lieutenant Colonel is the highest rank in the Armed Forces of the State of the Republic of Indonesia.

2. Because the September 30th Movement is basically a movement of lower-ranking Soldiers, especially of Enlisted Men and NCO's, it is herewith stated that all Enlisted Men and NCO's of all Armed Forces of the Republic of Indonesia who support the September 30th Movement are promoted one grade above those they occupied before September 30, 1965.

3. All Enlisted Men and NCO's who took a direct part in the purge against the members of the Council of Generals on the evening of september 30,1965 , in Djakarta are promoted to two grades above those they occupied prior to September $30,1965$.

Commandant of the September 30th Movement/Chairman of the Indonesian Revolution Council.

Signed: Lieutenant Colone1 Untung. Djakarta, October 1, 1965.

Announced by the Information Section of the September 30th Movement on October 1, 1965. 
5. AFFILIATIONS OF INDONESIAN REVOLUTION COUNCIL MEMBERS

[Compiled by the Editors]

Name Official Position Party Ethnic Group

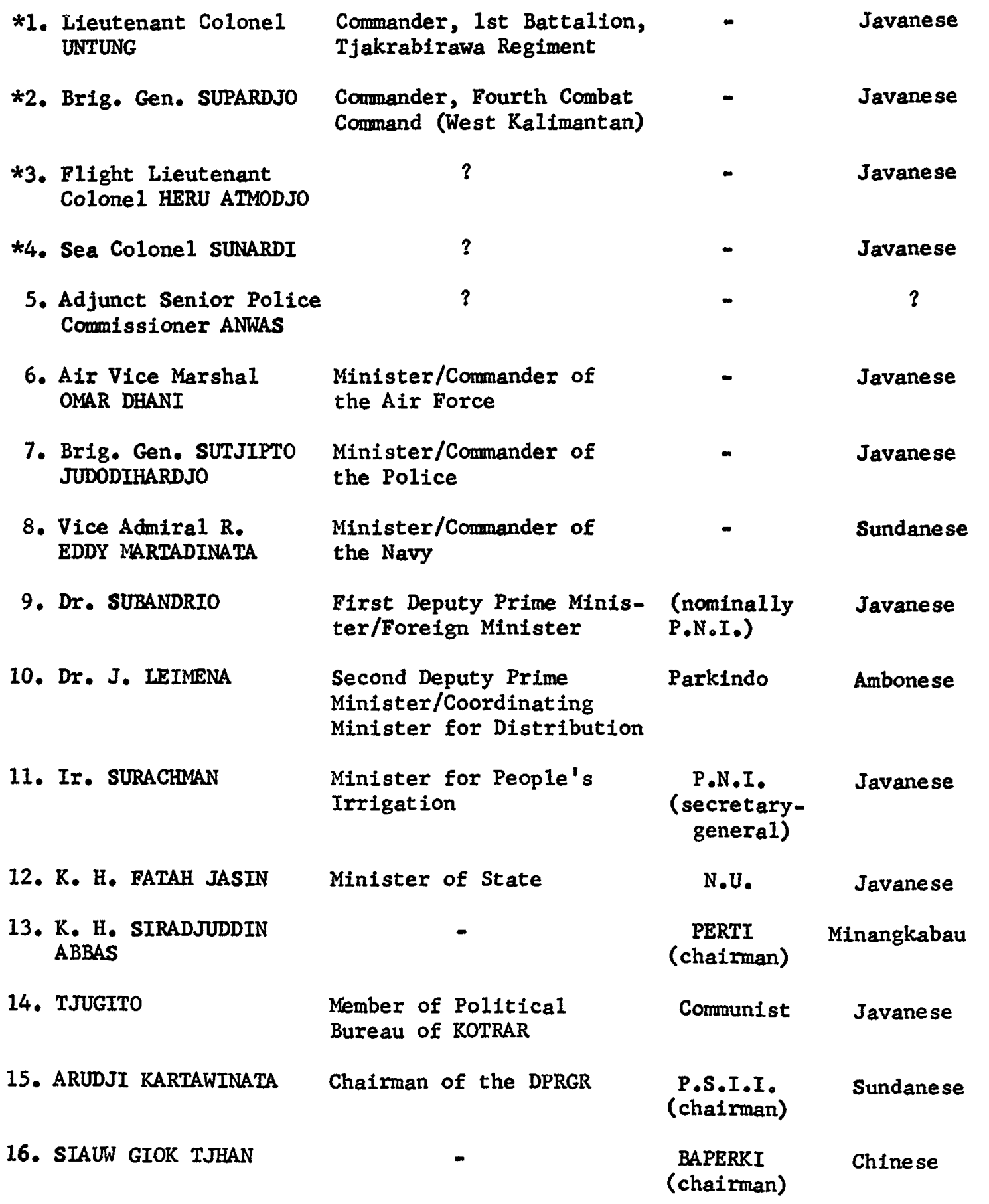
* An asterisk indicates the person concerned took an active part in the October
1,1965 , coup, so far as is known. 


\begin{tabular}{|c|c|c|c|c|}
\hline & Name & Official Position & Party & Ethnic Group \\
\hline 17. & SUMARNO, S. H. & $\begin{array}{l}\text { Coordinating Minister } \\
\text { for Finance }\end{array}$ & P.N.I. & Javanese \\
\hline 18. & $\begin{array}{l}\text { Maj. Gen. (Marine } \\
\text { Corps) HARTONO }\end{array}$ & $\begin{array}{l}\text { Commander of the Marine } \\
\text { Corps }\end{array}$ & - & Javanese \\
\hline 19. & $\begin{array}{l}\text { Police Brig. Gen. } \\
\text { SUTARTO }\end{array}$ & $\begin{array}{l}\text { Chief of Staff of Central } \\
\text { Intelligence Agency }\end{array}$ & 1 & Javanese \\
\hline 20 & ZAINI MANSUR & $\begin{array}{l}\text { Central Youth Front } \\
\text { (Presidium member) }\end{array}$ & $\begin{array}{l}\text { P.N.I. } \\
\text { (General } \\
\text { Chairman Gera- } \\
\text { kan Pemuda } \\
\text { Marhaenis) }\end{array}$ & Palembang \\
\hline 21. & JAHJA, S. H. & $\begin{array}{l}\text { Central Youth Front } \\
\text { (Presidium member) }\end{array}$ & $\begin{array}{l}\text { N.U. } \\
\text { (General } \\
\text { Secretary) }\end{array}$ & Javanese? \\
\hline 22. & SUKATNO & $\begin{array}{l}\text { Central Youth Front } \\
\text { (Presidiun member) }\end{array}$ & $\begin{array}{l}\text { Communist } \\
\text { (Secretary- } \\
\text { General Pe- } \\
\text { muda Rakjat) }\end{array}$ & Javanese \\
\hline 23. & BAMBANG KUSNOHADI & P.P.M.I. (Chairman) & $\begin{array}{l}\text { P.N.I. } \\
\text { (Chairman of } \\
\text { the G.M.N.I.) }\end{array}$ & Javanese \\
\hline 24. & ABDUL RACHMAN & $\begin{array}{l}\text { National Front (Deputy } \\
\text { Secretary General) }\end{array}$ & N.U. & $?$ \\
\hline 25. & HARDOJO & $\begin{array}{l}\mathrm{D} \cdot \mathrm{P} \cdot \mathrm{R} \cdot \mathrm{G} \cdot \mathrm{R} \cdot \text { (Youth } \\
\text { Representat ive) }\end{array}$ & Communist & Javanese \\
\hline 26. & $\begin{array}{l}\mathrm{Maj} \cdot \mathrm{Gen} \cdot \mathrm{BASUKI} \\
\text { RACHMAT }\end{array}$ & $\begin{array}{l}\text { Commander, East Java } \\
\text { (VIII) Territorial } \\
\text { Division }\end{array}$ & - & Javanese \\
\hline 27. & Brig. Gen. RYACUDU & $\begin{array}{l}\text { Commander, West Kali- } \\
\text { mantan (XII) Terri- } \\
\text { torial Division }\end{array}$ & - & Ambonese \\
\hline 28. & Brig. Gen. SOLICHIN & $\begin{array}{l}\text { Commander, South and } \\
\text { Southeast Sulawesi (XIV) } \\
\text { Territorial Division }\end{array}$ & - & Sundanese \\
\hline 29. & $\begin{array}{l}\text { Brig. Gen. AMIR } \\
\text { MACHMUD }\end{array}$ & $\begin{array}{l}\text { Commander, South } \\
\text { Kalimantan (X) Terri- } \\
\text { torial Division }\end{array}$ & - & Sundanese? \\
\hline 30. & $\begin{array}{l}\text { Brig. Gen. ANDI } \\
\text { RIVAI }\end{array}$ & $\begin{array}{l}\text { Governor of South and } \\
\text { Southeast Sulawesi }\end{array}$ & - & Buginese? \\
\hline
\end{tabular}


Name

*31. F1ight Major sUJONO

32. Air Commodore LEO WATTIMENA

33. Mrs. UTAMI SURJADARMa

*34. Colone1 A. IATTEF

35. Maj. Gen. UMAR WIRAHADIKUSUMAH

36. Mrs. SUPENI

37. Mrs. MAHMUDAH MAWARDI

38. Mrs. SUHARTI SUWARTO

39. Colone1 FATAH

*40. Colone 1 SUHERMAN

41. Sea Colonel SJAMSU SUTJIPTO

42. SUHARDI

43. Senior Police Commissioner Drs. SUMARTONO

44. DJUNTA SUWARDI

45. A. KARIM D. P.

\section{Official Position}

Cormander of the Guard at Halim Airbase

Commander of the AURI Operations Command/Halim Airbase; Chief of Staff, Mandala Siaga Command

Rector of Respublica University (BAPERKI)

Commander, 1st Infantry Brigade, Djakarta Raya (V) Territorial Division

Commander, Djakarta Raya (V) Territorial Division

Third Deputy Foreign Minister

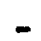

First Assistant to the Chief of Staff, Central Java (VII) Territorial

Division

Chief of the Navy

Information Centre

Head of Legal Depart-

ment, P.W.I. (Centra1)

Chief of Police, East

Kalimant an (XIV)

Police District

Chairman P.W.I. $\underline{\text { Party }}$

Ethnic Group

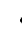

Javanese

$-$

Ambonese

Javanese

Sundanese?

Sundanese

P.N.I.

Javanese

N.U.

Javanese

(Ketua

Muslimat)

Communist

Javanese

(2nd

Chairwoman

GERWANI)

$?$

Javanese

-

Javanese

Javanese

- Javanese

- Javanese?

- Javanese

- Javanese?

P.N.I. Bugine se 


\section{STATEMENTS BY THE INDONESIAN AIR FORCE}

1. Air Force Commander Dani's Order of the Day. Issued at 9:30 a.m., October 1 and Broadcast at about 3:30 p.m. The following translation is based on the virtually identical Indonesian texts appearing in Antara (Warta Berita), October 1 (Afternoon Edition); Harian Rakjat, October 2; and Berita Yudha, October 4. An English translation of the Djakarta radio broadcast of october 3 has also been consulted. The only significant divergences among these four texts are that the Antara and Berita Yudha versions fail to say where the statement was issued; and the Antara and Harian Rakjat reports omit the Press Release Number provided by the other two sources.

In addition to the sources cited above, Dani's Order of the Day also appeared in at least two of the afternoon Djakarta papers for October 1, namely the leftist papers Warta Bhakti and Gelora Indonesia. The more conservative Protestant afternoon paper Sinar Harapan, which would have less reason to be pleased by the professed intentions of the September 30 th Movement, did not publish the Dani order. It is important to note also that this Dani order was broadcast by the Untungcontrolled Djakarta radio at about $3: 30 \mathrm{p} \cdot \mathrm{m}$. on October 1 .

Finally, it is of interest that this Dani Order of the Day also figures prominently in the immediate aftermath of the events of October 1. On October 3 the Army-controlled Djakarta radio repeatedly broadcast this October 1 Dani order, but always following it with Dani's statement of October 2 at Halim Air Base (See below for the text). The second statement was presented "as a correction of the Order of the Day." The same treatment is given to the Dani statements in Berita Yudha for October 4.]

Press Release No. 445/Pen/1965 on the Order of the Day of the Minister/Commander of the Indonesian Air Force.

(Text) Today, Friday, October 1, 1965, at 09:30 hours, the Minister/Commander of the Indonesian Air Force, Air Vice Marshal Omar Dani, issued the following Order of the Day:

1. On the night of September 30, 1965, the September 30th Movement launched a movement to secure and safeguard the Revolution and the Great Leader of the Revolution against C.I.A. subversion. In this connection, the body of the Army has already been purged [diadakan pembersihan] of those elements who are manipulated by foreign subversives and who endanger the Indonesian Revolution.

2. With the establishment of the aforementioned movement, foreign subversives and their henchmen will not remain idle and 
will very likely intensify their anti-revolutionary movement.

3. The Indonesian Air Force as an instrument of the Revolution will always and continuously support and uphold any progressive revolutionary movement. Conversely, the Indonesian Air Force will combat any action which endangers the Indonesian Revolution.

4. Herewith we order all members of the Indonesian Air Force to maintain vigilance against provocations and harassments and to intensify preparedness against all eventualities, internal as well as external.

\section{Signed}

(OMAR DANI)

Air Vice Marshal

Issued at: Department of the Indonesian

Air Force.

Date: October 1, 1965. Time: 09:30

2. Air Force Commander Dani's Statement in Jogjakarta. Issued on 0ctober 2, presumably before mid-afternoon.

The translation is based on the Indonesian text appearing in the October 4 report of the Jogjakarta daily Kedaulatan Rakjat. It is noteworthy that this issue would have appeared before loyalist troops under Diponegoro Commander Brigadier General Surjosumpeno retook Jogjakarta. As far as the editors know, this Dani statement has never appeared in the Djakarta press.

While the news report containing the text of the Dani statement gives October 2 as the date of issuance, it is not clear precisely when it was put out. It has been widely reported that Dani flew from Halim Air Base, outside of Djakarta, to Jogjakarta, sometime between midnight and $3: 00 \mathrm{a} . \mathrm{m}$. on the morning of october 2. (See, for example, Api Pantjasila, October 14). It is also known that Dani appeared at the Koti meeting in Bogor late on the afternoon of nctober 2. (See the Suharto october 15 speech cited below). Accordingly the presumption is that Dani issued the statement sometime during his approximately twelve hour stay in Central Java. The fact that the statement apparently appeared only in the Jogjakarta newspaper is the best ground for assuming that the statement was issued in the vicinity of that city -- very likely at the Adisutjipto Air Force Base. In this latter regard, however, it is noteworthv -- but perhaps understandable -- that the Commander of that air base makes no reference to Dani in his press statement published in Berita Yudha, November 30 .

The headline and introductory paragraph of the news report on the Dani statement are also given below.] 
BUNG KARNO CAME ON HIS ONN TO HALIM AIR BASE

Fighting Avoided After Misunderstanding Corrected

Minister/Commander of the Air Force Omar Dani on October 2 issued a statement about the condition of President Sukarno and exolained that there had been no effort to kidnap our beloved Bung Karno. The complete text of the statement is as follows:

[TEXT] 1. To clear up conflicting reports about the Indonesian Air Force in the last few days it is thought necessary to issue a statement to clarify the true situation.

2. On the morning of Friday, October 1, 1965, the President/ Supreme Commander of the Armed Forces/Great Leader of the Revolution agreed [berkenan] to come to the Halim Perdanakusuma Air Base voluntarily Latas kehendak Beliau sendiri] because this was the only place he regarded as truly safe in the Djakarta area at that time.

3. The President/Supreme Commander of the Armed Forces/ Great Leader of the Revolution is safe and well.

4. On that day talks were also held between the President/ Supreme Commander of the Armed Forces/Great Leader of the Revolution, the Second Deputy Prime Minister [Leimena], the Commander of the Navy [Eddy Martadinata], the Commander of the Police [Sutjipto Judodihardjo] and various other leaders concerning the situation in the capital which was still not at all clear.

5. As a result of these talks, inter alia the President issued an Order of the Day the text of which was also at that time sent to the RRI studio in Djakarta for broadcasting.

6. The essential contents of this Order of the Day were:

a. The President/Supreme Commander of the Armed Forces/ Great Leader of the Revolution is safe and well.

b. The President/Supreme Commander of the Armed Forces/ Great Leader of the Revolution continues to hold [tetap memegang] the top leadership of the state and revolution.

c. The leadership and the problems of the Army have been taken over by the President/Supreme Commander of the Armed Forces/Great Leader of the Revolution and the daily tasks have been turned over for the time being to Maj. Gen. Pranoto. 
d. All units of the Armed Forces are to stand fast, meaning that units must remain in their own quarters and may not act until they receive orders from the President/Supreme Commander of the Armed Forces/ Great Leader of the Revolution.

7. On the night of October 1, 1965, units of the Army which were opposed to one another were confronting each other around the Halim Perdanakusuma Air Force Base and it was thought that fighting would break out. For the safety of the President/Supreme Commander of the Armed Forces/Great Leader of the Revolution and of his own free will, he agreed [berkenan] to leave Halim Perdanakusuma Air Force Base.

8. In harmony with the contents of the Order of the Day of the President/Supreme Commander of the Armed Forces/Great Leader of the Revolution and to avoid the possibility of undesired bloodshed, units of the Air Force with the task of guarding Halim Perdanakusuma Base made no resistance whatever when units of the Army entered and occupied the Base on the morning of October 2, 1965.

9. Accordingly, it is stated that the whole membership of the Indonesian Air Force always and continuously stands behind the President/Supreme Commander of the Armed Forces/ Great Leader of the Revolution and obeys all his orders.

This is an official announcement of the Indonesian Air Force, signed by the Minister/Commander of the Air Force, Air Vice Marshal Omar Dani.

3. Deputy Air Force Commander's Statenent. Issued at 2:00 D.m., October 2.

The following translation is based on the Indonesian text appearing in Berita Yudha of October 4 and an English translation of the Djakarta radio broadcast of the statement on the evening of October 2. Although broadcast by Army authorities several hours before the statement of Omar Dani issued at Halim Air Base on October 2, it is not yet clear whether in fact that Dani statement appeared after or before the statement here.]

[TEXT] Announcement of the Information Center of the Department of the Air Force of the Republic of Indonesia No. 446/Pen/1965, on the continued obedience and loyalty of the Indonesian Air Force to the President/Supreme Commander of the Armed Forces/ Great Leader of the Revolution:

1. In view of the fact that the names of a number of officers 
of the Indonesian Air Force have been included in the so-called Indonesian Revolution Council which was set up by the counterrevolutionary group which calls itself the September 30 th Movement, it is hereby announced that the officers concenned, as well as the Department of the Air Force of the Redublic of Indonesia, have absolutely no knowledge of the composition or purpose of the so-called Revolution Council.

2. All Dersonnel of the Indonesian Air Force are urged to continue to be vigilant and obedient while awaiting further orders from the President, Bung Karno. The Ain Force of the Republic of Indonesia continues to safeguard unity and harmony of the progressive revolutionary forces and tools of the Revolution, in order jointly to destroy the counter-revolutionaries and Nekolim, who are endangering the Revolution and the State of the Republic of Indonesia.

3. All members of the Air Force of the Republic of Indonesia are urged to enhance their vigilance and continue to carry out their respective tasks as usual.

Issued at the Department of the Air Force of the Republic of Indonesia on October 2, 1965, at 14:00 hours.

In the name of the Minister/Commander of the Indonesian Air Force, Deputy Minister/Commander of the Air Force.

Signed

Air Commodore Andoko

4. Air Force Commander Dani's Statement at Halim Air Base. Issued sometime after 4:00 p.m., October 2.

The following translation is based on the Indonesian text appearing in Berita Yudha of October 4. An English translation of the Djakarta radio broadcast of October 3 has also been consulted and provided the additional information that the statement was apparently issued at Halim Air Base, presumably after Dani's return from Central Java at about 4:00 D.m. on October 2. See introductory note above for the October 1 Dani Order of the Day.]

The statement of the Indonesian Air Force, No. 005/207/65, is as follows:

1. The Indonesian Air Force is not involved in the September 30 th Movement.

2. The Indonesian Air Force agrees with any purging movement [gerakan pembersihan] which is established within the body of any instrument of the Revolution in conformity with 
the line of the Great Leader of the Revolution.

3. The Indonesian Air Force does not interfere in the internal affairs of other services.

4. The Indonesian Air Force has no knowledge of the Indonesian Revolution Council or of the composition of its personnel.

\author{
Minister/Commander of the Air Force \\ Signed: Omar Dani, Air Vice Marshal \\ Halim Perdanakusuma Air Base \\ October 2, 1965 .
}

5. Statement of the 7 th Regional Air Command of Central Java. Issued near Jogjakarta on October 2. Translation is based on the Indonesian text found in the Semarang daily Gema Massa of October 8, 1965. As far as is known, this statement did not appear in the Djakarta press: Adisutjipto Air Force Base is near Jogjakarta.]

Statement of the 7 th Regional Air Command of Central Javal Jogjakarta Special Region, No: Korud VII/010/65:

1. The 7 th Regional Air Command agrees with any purging movement [gerakan pembersihan] which is established within the body of any instrument of the revolution.

2. The 7 th Regional Air Command does not interfere in the internal affairs of other services.

3. The 7th Regional Air Command continues to preserve unity and harmony while remaining vigilant for provocation and harassment.

4. The 7th Regional Air Command stands behind the Great Leader of the Revolution without reserve and will follow all of His Excellency's orders.

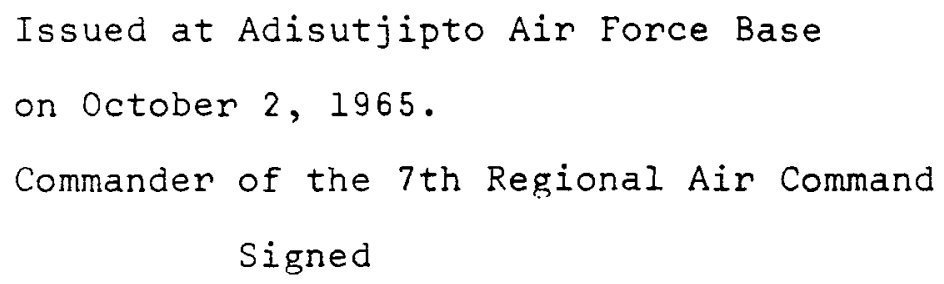


6. Statement by the Commander of the Panasan Air Force Base. Issued near Surakarta on October 3 .

The translation is based on the Indonesian text found in Kedaulatan Rakjat (Jogjakarta daily), October 12. The text of the entire news report is given. Panasan Air Force Base is near Surakarta.]

The Commander of Panasan Air Force Base, Flight Lieutenant Colonel Soejoto, on October 3, 1965, issued a statement at Panasan Air Force Base, No. Pns/OL/65, as follows:

A. The Message of His Excellency President/Supreme Commander of the Armed Forces/Great Leader of the Revolution Bung Karno, dated October 1, 1965.

B. The statements of the Honorable Minister/Commander of the Air Force Air Vice Marshal Omar Dani, the first dated October 1, 1965, and [the second ?] no. Dep. 05/207/65, dated Dctober 2, 1965 .

C. Statement of the 7 th Regional Air Command of Central Java, no. Korud VII/010/65.

1. Panasan Air Force Base agrees with any purging movement [gerakan pembersihan] which is established within the body of any instrument of the revolution.

2. Panasan Air Force Base does not interfere in the internal affairs of other services.

3. Panasan Air Force Base continues to preserve unity and harmony.

4. Panasan Air Force Base stands behind the Great Leader of the Revolution without reserve and will follow all of His Excellency's orders.

Statement issued over RRI Surakarta on Monday, October 4, 1965, at $06: 30 \mathrm{a} . \mathrm{m}$. 

III. STATEMENTS BY PRESIDENT SUKARNO AND
THE TJAKRABIRAWA REGIMENT

1. Announcement by the Tjakrabirawa Commander. Issued at 12:00 P.M., October 1 and Broadcast at I:10 D.m., October 1 . [During the period in which the Untung group controlled the Djakarta radio there were no broadcasts by President Sukarno himself or of statements or orders attributed to him. The President's Order of the Day (See item 2. below) was for unexplained reasons not broadcast -- although it was issued well before the Untung group surrendered control of the radio. Accordingly, the announcement by Brigadier General Sabur, Commander of the Tjakrabirawa Regiment [the President's "palace guard"], broadcast by the Untung-controlled radio at $1: 10$ p.m. october 1, constitutes the only authoritative news of the President released by the Untung radio. Considering that in the wake of the events of October 1 General Sabur has not disowned this statement and has still retained his position, it seems clear that his announcement of october 1 was indeed authoritative -- i.e. authorized by the President himself.

The translation given below is of the lead story in the October lst afternoon edition of the Djakarta newspaper Sinar Harapan. It gives not only the text of the actual sabur announcement -- identical to the announcement as broadcast over the Untung radio at 1:10 p.m.-- but some significant details about the time and place of issue as well as the fact that Sabur himself was not present when the statement was issued. Moreover, Sinar Harapan's treatment of the Sabur announcement as its feature storv is in itself of significance. Unlike the leftist afternoon Dapers, such as Warta Bhakti, Gelora Indonesia, Kebudajaan Baru and Ekonomi Nasional, this Protestant Party newspaper refrained from publishing any of the broadcasts of the Untung-controlled radio. The only news report it published relating to the September 30 th Movement -though never explicitly mentioning it by name -- was this Sabur statement which apparently it secured in press release form because, it printed information not provided in the $1: 10 \mathrm{p} . \mathrm{m}$. radio broadcast. It should be pointed out, however, that since Sinar Haradan normally goes to press at least an hour after the other afternoon Djakarta papers, its editors had more time to learn that by mid-afternoon the tide had begun to turn against the Untung forces.]

\section{PRESIDENT CONTINUES TO EXECUTE STATE LEADERSHIP}

President Sukarno is safe and well and continues to execute [tetap dialankan] the leadership of the State. Such was the announcement by the Commander of the Tjakrabirawa Regiment, Brigadier General Mochammad [c apparently an error] Sabur, early Friday afternoon, at $12 \overline{000}$ in the Headquarters of the 
Tjakrabirawa Regiment.

The complete text of the official statement as read by the Chief of Staff of the Tjakrabirawa Regiment, Lieutenant Colonel Merokeh Santoso, is as follows:

"In order to prevent inappropriate reports and interpretations, I herewith announce that His Excellency the President/ Great Leader of the Revolution is safe and well, and continues to execute the leadership of the state."

2. President Sukarno's Order of the Day Appointing Major General Pranoto as Caretaker of the Army. Reportedly Issued at 1:30 p.m., Dctober 1. The translation is based on the Indonesian text appearing in Antara, October 2 (Morning Edition). Although the time and place of the issuance of this statement are not given in the Antara report, the presumption is that it was issued from Halim Air Base early on the afternoon of October 1. The Indonesian Daily News (Surabaja) of October 4 gives 1:30 p.m. as the time of issuance.]

The President/Supreme Commander of the Armed Forces/Great Leader of the Revolution makes the following announcement:

1. As President/Supreme Commander of the Armed Forces/Great Leader of the Revolution, I hereby announce:

That I am safe and well and continue to hold the leadership of the state and the revolution.

That the leadership of the Armed Forces of the Republic of Indonesia is temporarily directly in the hands of the President/Supreme Commander of the Armed Forces.

That Major General Pranoto Reksosamudro, Third Assistant to the Minister/Commander of the Army, has been temporarily appointed to carry out dav-to-day tasks within the Army.

2. I command the entire Armed Forces of the Redublic of Indonesia to heighten their preparedness, to return to and stay at their respective posts, and only move on orders.

3. The entire public is ordered to remain calm, enhance their vigilance, and preserve harmony and national unity as closely as possible.

$$
\begin{aligned}
& \text { Issued in Djakarta, on October } 1,1965 . \\
& \text { The President/Supreme Commander of the } \\
& \text { Armed Forces, Great Leader of the Revolution, } \\
& \text { signed }
\end{aligned}
$$


3. Announcement by the Tjakrabirawa Commander Following the Collapse of the September 30th Movement. Broadcast at 12:I5 a.m., October 2. This broadcast was made at $12: 15$ a.m., October 2, after RRI Djakarta was again in Army hands. The translation is based on the text given in Berita Yudha, october 2, 1965. The reader's attention is drawn to the curious textual discrepancy between this announcement and that made by Sabur while the Untung group still controlled Djakarta Radio. (See above item 1 in this section.)]

\author{
Bung Karno \\ Reassumes Leadership \\ of the State
}

The Commandant of the Tjakrabirawa Regiment, Brig. Gen. M. Sabur, in his announcement broadcast over RRI at $12: 15 \mathrm{a} . \mathrm{m}$. Saturday morning, declared that the President/Supreme Commander of the Armed Forces/Great Leader of the Revolution Bung Karno was at present safe and well and had reassumed [kembali memegang] the leadership of the state.

4. President Sukarno's First Message Following the Collapse of the September 30th Movement. Broadcast at 1:33 a.m., october 3 . The translation is based on the Indonesian text in Berita Yudha of October 4.]

Brothers, repeating my order as Supreme Commander of the Armed Forces/Freat Leader of the Revolution which was announced on Dctober 1, 1965, and to eliminate all uncertainty among the people, herewith I once again declare that I am safe and well and continue to hold the top leadership of the state and the ton [leadership] of the government and the Indonesian Revolution.

Today, October 2, 1965, I summoned all Commanders of the Armed Forces, together with Second Dedutv Prime Minister, Dr. Leimena, and other important officials, with the purpose of quickly settling the problem of the so-called september 30 th Affair. To be able to settle this problem I have ordered the prompt creation of a calm and orderly atmosphere and for this purpose it is necessary to prevent any possibility of armed conflict.

In the present stage of the determined struggle of the Indonesian people, I command the entire population cantinuously to increase vigilance and preparedness in the framework 
of intensifying the implementation of Dwikora.

I appeal to all the Indonesian people to continue to remain calm and to all ministers and other officials continuously to carry out their respective duties as before.

At present the leadership of the Army is directly in my hands, and to discharge the day-to-day tasks within the Army, I have appointed temporarily Major General Pranoto Reksosamudro, Third Assistant to the Minister/Commander of the Army.

To carry out the restoration of security and order in connection with the September 30 th Affair, I have appointed Major General Suharto, Commander of KOSTRAD, in accordance with the policy I have already outlined.

Brothers, let us persist in nurturing the spirit of national unity and harmony. Let us steadfastly kindle the anti-Nekolim spirit. God be with us all.

5. President Sukarno's Second Message. Broadcast at 11:52 P.m., October 3 . The translation is based on the Indonesian text found in Berita Yudha of October 5. Also see the English translation of the Djakarta Radio broadcast for October 3.]

Brothers, in view of a number of misunderstandings which can create conflicts among the Armed Forces, to eliminate any uncertainty in the community, and to build stronger national unity and harmony in the framework of the Dwikora struggle, herewith I, as President/Supreme Commander of the Armed Forces/ Great Leader of the Revolution, announce that:

1. The charge against the Indonesian Air Force of involvement in the September 30 th Affair is not true.

2. My going to the Halim Air Base early on the morning of October 1 was at my own desire, as I was of the opinion that the best place for me was a place near an airplane which could transport me at any moment to another place if something unexpected took place.

3. We must remain vigilant and prevent the playing off against one another of the Air Force and the Army to the advantage of Nekolim and other groups.

Therefore, I order all members of the Armed Forces to unite for the security of the State and Revolution. That is all. Respect my order.

[ditempat], October 3, 1965

signed 
6. President Sukarno's First Press Interview after the Collapse of the September 30th Movement. Given and published on October 14 . [The translation is based on an Antara report carried in the Protestant news Daper Sinar Harapan, October 14, 1965].

(Antara). The President/Great Leader of the Revolution will formulate a political solution for the problem which has arisen as a result of the so-called "September 30 th Movement" on the basis of real facts and not on the basis of inflammatory statements from whatever quarter.

The President/Great Leader of the Revolution made this statement yesterday morning to the Chairman of the Board of Directors of the Antara National News Agency, Mohammad Nahar, in the Freedom Palace. This is the first press interview given by President Sukarno since the occurrence of the counter-revolutionarv adventure of the "September 30 th Movement".

When asked whether the President/Great Leader of the Revolution had already developed a formula for the political solution of the problem which has arisen because of the "September 30th Movement", the President/Great Leader of the Revolution answered: "Laat dat maar aan mij over. wait and see!" (Serahkan itu padaku. Tunggulah!) [Leave that to me. Just wait and see!]

The President immediately added that his political solution will be based upon "real facts" and not on the basis of inflammatory statements from whatever quarter.

According to information obtained by the Antara reporter, since the occurrence of the so-called "September 30th Movement" the President/Great Leader of the Revolution has been constantly busy, with very little time to rest, holding consultations and discussions with his ministerial assistants as well as the leaders of the Armed Forces and other important persons and leaders in order to discuss day-to-day governmental problems so that everything can run smoothly and normally.

\section{PRESIDENT STILL TRUSTS THE TJAKRABIRANA}

In the interview held on the back veranda of the Freedom Palace, where the President/Great Leader of the Revolution was busily conducting discussions and giving instructions to his assistants in the government, the President/Great Leader of the Revolution was also asked whether his trust in the Tjakrabirawa Regiment had been shaken in connection with the temporary involvement of elements of the Tjakrabirawa in the "Seotember 30th Movement". 
In this connection, the President made several comments and clarifications as to how the units of the Tjakrabirawa Regiment had carried out their duties at critical moments, in order to secure and safeguard the President/Great Leader of the Revolution. He explained that when, at his own desire and not because of pressure or threats from anyone, he left, Freedom Palace on the morning of nctober 1 to go to Halim Perdana Kusumah Air Base, those responsible for escorting and guarding him were units of the Tjakrabirawa, who carried out their duty most effectively. "So too when I left Halim for Bogor, those who escorted me -- 'escorted' in the good sense of the word [mengawal in de goede betekenis van het woord] -- were the Tiakrabirawa. Also at this point I wish to stress once again that my departure to Bogor was at my own desire [atas kehendak saja sendiri] and not because of any pressure or threats."

President Sukarno emohasized that his trip to Bogor was taken by car [dengan kendaraan bermotor] and not by helicooter.

Finally, the President also explained that as long as he was at Bogor and when he left Bogor for Djakarta on October 9 , units of the Tjakrabirawa Regiment were responsible for his personal security and that they performed their duties most efficiently.

7. Comments by the Tjakrabirawa Leadership on the Events of october 1. Published on October 14. The translation is based on an Antara report carried as a continuation of the story of the President's October 14th interview. See Sinar Harapan, October 14, 1965.]

As to how the President/Great Leader of the Revolution escaped from treachery and danger, and managed to be secured and saferuarded at critical moments on nctober 1 , the following comments have been received from the leadership of the Tiakrabirawa Regiment.

Early in the morning, of October 1 units dressed in Army uniform were placed around the Palace, as it were, encircling it.

The Tjakrabirawa leadership did not know the purpose behind the placement of these units, and since there were other susoicious signs, at about 6:00 a.m. Tjakrabirawa units immediatelv took the rapid and firm decision to take the President/ Great Leader of the Revolution out of the Palace, and bring him to safety in a place they considered secure.

From this olace, and at his own desire, the President/ Great Leader of the Revolution left for Halim Perdanakusumah Air Base, escorted by units of the Tjakrabira'sa, with the 
consideration that, should any undesirable eventualities occur, the Head of State could be immediately flown out to a safer place.

The Tjakrabirawa leadership emphasized that at that time no one knew for certain what had happened. Only later, when the President/Great Leader of the Revolution was in safetv, did it become known that there were elements within the Tjakrabirawa corps involved in the counter-revolutionary adventure of the "September 30 th Movement."

The President/Great Leader of the Revolution reached Halim Perdanakusumah Air Base at about 9:30 a.m. That night he left Halim Perdanakusumah Air Base. Tjakrabirawa units took the necessary actions for guarding and escorting him; at 10:30 p.m., escorted by Tjakrabirawa units, the President left the Air Base by car. The President/Freat Leader of the Revolution reached the Bogor Palace at about midnight, safe and sound [tanpa kurang suatu apa]. The whole move, from the Palace to Halim Perdanakusumah Air Base and on to Bogor, was carried out by car, and at no point was use made of the helicopter.

So long as the President/Great Leader of the Revolution was in the Bogor Palace (from midnight, October 1 to Saturday, October 9), security in and around the Palace was fully guaranteed, guard and escort functions being carried out by Tjakrabirawa units. At $9: 15 \mathrm{a} . \mathrm{m}$. on October 9 , the President/ Great Leader of the Revolution left Bogor to return to Freedom Palace in Djakarta.

This time he travelled by helicopter, and escort and guard functions were again performed by Tjakrabirawa units.

In this connection the leadership of the Tjakrabirawa Regiment stressed that naturally the Tjakrabirara Regiment was assisted in its security and escort duties bv units from the Armed Forces. Security movements in areas outside those for which the Tjakrabirawa Regiment was responsible were carried out by units of the Armed Forces in the closest cooperation and coordination with the Tjakrabirawa Regiment.

In this connection reference was made to the safeguarding and escorting of the children of President Sukarno during the crisis. At about 4:00 p.m. on October 1, the President's children were taken from Freedom Palace to Kebajoran, and later on, to Halim Perdanakusumah Air Base. This operation was carried out by the Tjakrabirawa to guard against all possible eventualities. From Halim Perdanakusumah Air Base the President's children were subsequentlv taken bv helicooter to Bandung. In Bandung escort and guard duty were assumed jointly by units of the Tjakrabirawa, the Kudjang Battalion, 
the [Air Force] Pasukan Gerak Tjepat and the Mobile Brigade [Police].

All guard and escort assignments were performed in the best possible manner thanks to excellent cooperation between units of the different Armed Forces.

In conclusion the leadership of the Tjakrabirawa Regiment stressed that not for one moment had the President/Great Leader of the Revolution ever been in the power of the so-called "September 30 th Movement." 
IV. STATEMFNTS BY THE INDONESIAN ARMY LEADERSHIP

1. First Army Broadcast After Recovering Control of the Djakarta Radio. As Broadcast at about 8:45 p.m. , October 1. The translation is based on the Indonesian text found in Berita Yudha of October 2 and the English translation of the Djakarta Radio broadcast of $8: 45 \mathrm{p.m}$., October 1.]

We express our gratitude to God Almighty that we, the Radio of the Republic of Indonesia, have been liberated from counter-revolutionary control by our armed forces, who have been constantly loyal and recognize only Bung Karno as the Great Leader of the Revolution.

We will now present an announcement.

Announcement No. 027/1965 of the Armv Information Center.

1. On October 1, 1965, an incident occurred which was carried out by a counter-revolutionary movement, which called itself the "September 30th Movement", in Djakarta.

2. They kidnapped a number of high officers, namely: 1. Lieutenant General A. Yani. 2. Major General Suprapto. 3. Major General S. Parman. 4. Major General Harjono M.T. 5. Brigadier General D.I. Pandjaitan. 6. Brigadier General Sutojo Siswomihardjo.

3. They were able by force to gain the use of the Djakarta Studio of RRI [Radio Republik Indonesia] and the Djakarta Central Telecommunications office.

4. His Excellency, President/Supreme Commander of the Armed Forces/Great Leader of the Revolution Bung Karno, and his Honorable Minister Coordinator for Defense and Security/ Chief of Staff of the Armed Forces, General A. H. Nasution, were able to be brought to safety and are in a safe and well condition.

5. The leadership of the Anmy is temporarily held by Major General Suharto, Commander of KOSTRAD.

6. The general situation is again under control and security measures are being actively carried out. The general public is urged to remain calm and continue their respective tasks as usual. 
2. Army Commander Suharto's Charge of Air Force Involvement in His Statement Made Upon Discovery of the Bodies of the Generals on October 4. The translation is based on the report in Berita Yudha of October 5 and English translation on Djakarta Radio broadcast on the evening of October 4.]

Today, October 4, 1965, we witnessed together, with our own eyes, the recovery of the bodies of our generals -- six generals -- and one junior officer from an old well. As you already know, our generals and our junior officers have fallen victims to the uncivilized actions of the adventurers of the so-called "September 30 th Movement."

If we survey the place, it is in Lubang Buaja. Lubang Buaja is within the area of the Halim Air Base. Here you will also see that the area near the well has been used as a training center for volunteers under the auspices of the Air Force. The volunteers consisted of members of the Communist Youth Group [Pemuda Rakjat] and of the Communist Women's Organization [Gerwani].

In a word, it is possible that they were undergoing training in the framework of the defense of the airbase. But with the capture in Tjirebon of a member of Gerwani who had been trained here and who hails from Central Java, it is clear that they come from far away. Thus, based on these facts, it is possible that there is truth in the statement by our beloved President Bung Karno that the Air Force is not involved in the affair. But it is impossible that there is no involvement in this affair of elements of the Air Force.

For this reason, as a member of the Army, I would like to express the sentiment of patriots who are members of the Army: If it is true that there are elements who are involved in the cruel killing of our innocent generals, I hope that Air Force patriots will purge such elements who are involved in this adventure.

I am very grateful that finally God gives clear guidance to us, that any dishonest action, that any bad action certainly will be suppressed. And I am grateful to units, particularly those from the paratroop regiment [RPKAD] and the marines [KKO] and other units, and the people who have assisted in the discovery of the well and the recovery of the bodies, so that the number of the victims could be determined. That is all. 
3. Speech by Major-General Suharto on October 15, 1965, To Central and Regional Leaders of the National Front.

Mr. Secretary-General, brothers from the National Front Central and Regional Leadership:

First of all I would like to thank you very much for the opportunity afforded me at today's meeting of the Central and Regional [leadership] of the National Front, and for the chance given me to convey certain explanations and clarifications, particularly about the task delegated to me by the President, Supreme Commander of the Armed Forces, Great Leader of the Revolution, in confronting the recent developments which we have all been experiencing and witnessing together in connection with the September 30th Movement. I would like to use this opportunity to pass on to you the facts as far as we know them, because I think that the facts will say more than I can, provided that we can evaluate those facts objectively. It will be up to you, my brothers, to make your own assessments - I shall simply try not to add or subtract anything. from what I myself saw happening. I have no intention of influencing you all, my brothers, in making your own assessments of the facts which I experienced since October 1. Apart from giving you these facts myself, I [would like to request] time for other clarifications, since though $I$ myself know some of the relevant facts, a number of my staff officers have also been able to collect some facts. I would like therefore to request time for my assistant, General sutjipto, to give some explanations of his own.

Before I start I would like to ask your forgiveness, my brothers, for any lack of polish and coherence in my analysis, and also for any imperfections in my language - I am no expert at public speaking. I think we have a friend here who knows me, $\mathrm{Mr}$. Harjo Sudirdjo, $(1)$ who is also from Jogja; [he knows that] I am someone who very rarely makes public statements, so that now that I am making a speech, especially to you, my brothers from the Central and Regional National Front leadership, this will more or less influence the rather disorganized form of what I have to say. So I ask your pardon in advance for any such deficiencies.

My brothers, very early in the morning of October 1, about 5:30 a.m., I was visited by one of my neighbours. As I happen to

(1) The reference is to the Minister for water Supply. 
be the head of the Rukun Tetangga (2) in my kampung, he wanted to report to me - to fulfil his obligation as a Rukun Tetangga member to report if he heard or saw anything [unusual]. He told me that early that morning shots had been heard, that there had been shooting, and that they had heard that there had been kidnappings. Among other things he told me, he informed me that those who had been kidnapped included General Nasution, General Yani, General [Su]Prapto, General Parman, General Harjono, General Pandjaitan, General Sutojo and also Pak Leimena; lastly he reported or informed me that (Air) Marshal Umar Dhani [sic] was also among those kidnapped. (3) Soon afterwards another neighbour came round to report the same thing.

Their story was confirmed with the arrival of a General, a colleague of mine, a colleague from the Army, who gave me the same information. None of them, in giving their reports, had any idea of what, at that moment, was the fate of the kidnapped Generals.

So I was able to draw the conclusion that the Army leadership could be said to be paralyzed. Since the Commander, the Minister/Commander, together with his Deputies and Assistants, had all been kidnapped, this meant that the Army had lost its leadership. Therefore I took a decision - since I was convinced that if the Army, the largest element in the Armed Forces, was without its leadership, it would become still more confused, particularly confronted with a situation of this kind. Aside from the fact that it was normal practice, if the Minister/Commander of the Army went abroad, - normal practice since I was regarded as the senior officer after the Minister/Commander of the Army - for me to be appointed to represent him, (although functionally speaking it should have been the First or Second Deputy who represented him, the Minister decided that even if the First and second Deputies were available, I would always be appointed to take his place as Minister/Commander of the Army when he was away) anyway, even aside from this normal practice, as an officer I realized that if any unit, even a small unit, let alone a large one, should be separated from its leadership, the consequence would be immediate chaos.

(2) The Rukun Tetangga are neighbourhood associations with various economic, security and intelligence functions.

(3) General Nasution is Defense Minister/Chief of Staff of the Armed Forces; and General Yani was Minister/Commander of the Army; General Suprapto was Second Deputy to the Minister/Commander of the Army; General Parman was First Assistant (Intelligence) to the Minister/Commander of the Army; General Harjono was Third Deputy to the Minister/Commander of the Army; General Pandjaitan was Fourth Assistant (Logistics) to the Minister/ Commander of the Army; General Sutojo was Auditor-General and Law Inspector of the Anmy; Dr. Leimena is Second Deputy Prime Minister/Coordinating Minister for Distribution; Air Vice Marshal Omar Dhani was Minister/Commander of the Air Force. 
Therefore, unged on by a desire that, since the Army is also an instrument of the Revolution which must always be ready to render service to the State, to the Revolution, to the Great Leader of the Revolution, every effort should be made to ensure that this very considerable force retain its leadership, without hesitation I decided on my own to assume leadership of the Army, so long as we remained in the dark about the fate of the Minister, the honorable Minister of the Army.

Since it was still very early, and so my chauffeur had not yet arrived, I was forced to drive myself in a Jeep to Headquarters, KOSTRAD hegdquarters, where indeed I was stationed as KOSTRAD Commander. $(4)$ On reaching Headquarters, I learnt that several of my Staff officers had already arrived, since it was already almost 7:00 a.m., or at least well after 6:30 a.m. I therefore immediately collected my Staff together. It turned out that among all my Staff officers, there was not one who knew anything about the affair. In fact the affair was very alarming [mengedjutkan] for all of us, both for the KOSTRAD people and for the Army in general.

Since there was in Djakarta an officer with direct responsibility for security - the Commander of the Fifth (Djaya) Territorial Command - I contacted him, (5) and learned that he had visited the various places where the events [kidnappings] had occurred, and had then gone straight to the Palace to see His Excellency the President. However he did not get to meet the President himself, but he did encounter or rather observed that General Supardjo was inside the Palace. I should explain that General Supardjo was actually Commander of the Fourth Combat Command, in fact within the Confrontation framework he was in command of the Fourth Combat Command of KOSTRAD, and should have been at his post in West Kalimantan. They had set up their command post there in West Kalimantan, near Menggaian. As KOSTRAD Commander and as Deputy Commander of the Mandala Preparedness Command - in the first case having direct administrative responsibility for directing or preparing KOSTRAD units, and in the second case having direct tactical command - I was rather startled to learn that General Supardjo had come to Djakarta at all, let alone that he was at the Palace very early in the morning, without letting either KOSTRAD or the Mandala Preparedness Command know beforehand, and especially myself as Deputy Commander of the Mandala Preparedness Command.

At this point, having received General Umar's report and explanation, I informed him, I told him clearly that I was taking over leadership of the Army. He agreed, and $I$ then issued my first command and instruction to him as Commander of the Djaya

(4) KOSTRAD is the Army Strategic Reserve Command.

(5) This was Major General Umar Wirahadikusumah. 
Territorial Command. My first order was that all troops be consigned to their quarters. No one was to go out without direct orders from me. If in the framework of restoring security it should prove necessary [for anyone] to leave their quarters, they must wear civilian clothes. This was intended to prevent misunderstanding [simpang siurnja] between various units, since we still did not know who was friend and who foe. The main idea was thus to avoid the possibility of shooting breaking out till we knew for sure who was friend and who foe. This order was then carried out by the Djaya Territorial Commander.

I then tried to contact the Navy. (6) Now it happened that the First Deputy of the Minister/Commander of the Navy was also a Deputy Commander of the Mandala Preparedness Command, so that there was already good coordination between Admiral Muljadi and myself. In a very short time he came round to KOSTRAD Headquarters. After I had explained the whole situation, he proposed and agreed that for the time being I should assume command, and that [the Navy] would give its fullest support to the Army in overcoming and settling the present situation. Since I had now been given authority to coordinate all Navy activities, I issued instructions like those [I had given to Umar]. All [Navy personnel] must be consigned to barracks. No one was to go out without direct orders from me. If compelled to leave [their quarters] to help restore order and security, civilian clothes must be worn.

Thirdly, I made contact with the Police. I could not get through directly to the Police Department, but I did succeed via the [Djakarta] Police Chief. (7) I did what I had done before with the Navy, and the Police Chief finally agreed to centralize all police movements, allowing me to coordinate police movements for the whole of the Djakarta area.

The one Force with which I had difficulty in making contact was the Air Force. I took the step of sending some liaison officers to Halim, because I knew several Air Force officers within the framework of the Mandala Preparedness Command. I did get in contact with various Air Force officers, particularly, Commodore Leo, but not as smoothly as with the Navy and Police. ( 8 ) In the

(6) It is worth noting that the Minister/Commander of the Navy Vice Admiral R. Eddy Martadinata, does not appear to have been contacted by Suharto.

(7) It is worth noting that the Minister/Commander of the Police, Police Inspector General Sutjipto Judodihardjo, does not appear to have been contacted by suharto. The Commander of the VIIth Police Region (Greater Djakarta) was Police Brig. Gen. Sawarno Tjokrodiningrat, appointed June 8,1965 . He was removed from this post shortly after the coup.

(8) Air Commodore Leo Wattimena was Commander of the Air Force Operations Command, Halim Perdanakusumah Air Base, and Chief of Staff of the Mandala Preparedness Command. 
case of the Navy and Police, once their leaderships had been contacted, they placed liaison officers at KOSTRAD HQ to facilitate relationships and to exchange whatever information each force received about what had happened. Thus it was only with the Air Force that there was some footdragging in setting up doordination that morning. The affair had still not developed to the point where we knew who was friend and who foe.

Still early in the morning, after I had made contact with the various Armed Services, I received word that General Nasution had been rescued - it was about $8: 00 \mathrm{a} . \mathrm{m}$. when I heard this and was now in a [safe] place. Secondly I got information that Air Marshal Umar Dhani [sic], who according to the first reports had been kidnapped, had actually been taken to safety [diselamatkan] by his own men [anak buah] at about 3:00 a.m., i.e. about one hour before the affair broke out - since the affair occurred roughly between $4: 00$ and $4: 30 \mathrm{a} . \mathrm{m}$.

At the same time I gave orders to collect as much information as possible; and so we learnt (and indeed I myself already knew) that the troops around the Palace were units wearing green berets.

The [only] units in Djakarta wearing green berets were Battalions 454 from Central Java and 530 from East Java. I should explain here that these units were [in Djakarta] to contribute to the grandeur of the Armed Forces Twentieth Anniversary. In other words they were not units on strictly military assignment [bukan kesatuan jang diperintahkan], but [because] the President wanted the Armed Forces Twentieth Anniversary to be celebrated on a grandiose scale [dengan meriah].

The Army was to display the formation it regularly puts on in the framework of a "show of forces" [sic]; it was going to demonstrate the formation of a full infantry combat brigade with supporting units - 3 battalions of foot, plus 1 tank, 1 armored (panzer), 1 mortar, 1 anti-aircraft and 1 engineers' unit. Thus [the idea was] to display the formation of a "strengthened" Army Infantry Brigade for the commemoration of the Anniversary.

Once we knew that the troops in the areas around the main intersections $(9)$ were wearing green berets, I summoned the Brigade Commander and demanded an explanation as to why these green beret troops from his Brigade were stationed around the Palace. Now it happened that I myself had held an Inspection of this Brigade on [September] the $30 \mathrm{th}$, with its [constituent] battalions, as part of the preparations for the Twentieth Anniversary display. In fact I even had an appointment to watch a training-rehearsal

(9) The text is confused here, literally reading: "setelah kami mengetahui bahwa jang berada disekitar lapang djalan silang kesatuan 2 baret hidjau...." 
on October lst itself, in which these troops were supposed to be ready at Senajan Stadium by $6: 30 \mathrm{a} \cdot \mathrm{m}$. The Brigade Commander answered my request for an explanation by reporting that the units of his Infantry Brigade were fully mustered, except for two battalions which had still not shown up, i.e. Battalions 454 and 530, which now proved to be stationed in front of the Palace and around the Istana Negara.(10)

Meanwhile, still quite early, as we were trying to gather as clear information as possible, the first announcement by former Lieutenant Colonel Untung, Commander of the lst Tjakrabirawa Battalion, was heard, saying that they were mounting a movement called the September 30 th Movement, to take action against a Council of Generals who were about to undertake a coup, and that this movement was intended to safeguard the Revolution. (II) This was the first real news that we had heard; from it we were able to conclude that this 'Movement' was a movement to paralyze what, according to them, was a movement by a Council of Generals to execute a coup.

As a member of the Army, I naturally knew better what the real situation within the Army was. The accusation(12) that a Council of Generals existed, which was on the point of carrying out a coup, made no sense at all to me, and so I drew the conclusion that these "bulletins" and "reasons" were simply concocted justifications.

The Council of Generals which they mentioned simply did not exist, let alone one which was organizing a coup. The truth is that within the Army there is a Council on posts and Ranks for Senior officers, abbreviated as WANDJABTI. (13) Its task is, every year as Proclamation Day comes around, to consider the promotions of Colonels to the rank of General; and this Council, this WANDJABTI, is headed by General Sudirman, $(14)$ with myself as Vice-Chairman. So I knew quite clearly that if what they meant

(10) The Presidential Palace is actually compounded of two separate buildings, back to back, separated by a large garden. The Istana Merdeka (Freedom Palace) looks south onto Djl. Merdeka Utara and Merdeka Square. The Istana Negara (State Palace) looks north onto Djl. Segara.

(11) This broadcast was made at approximately 7:15 a.m. over Radio Djakarta.

(12) The printed word is tudjuan (aim, intention). This seems to be a misprint for tuduhan (accusation).

(13) This abbreviation stands for Dewan Djabatan dan Pangkatan Perwira Tinggi.

(14) General Sudirman is head of the Army Staff and Command School. 
by the Council of Generals was this Council WANDJABTI, then it had absolutely no intention whatever, let alone any plans for making a seizure [of power] or a coup. If what they meant was the group of Generals on the General Staff (SUAD), who acted as advisers to the Minister/Commander of the Army in leading the Army and situating [menempatkan] it as an instrument of the Revolution, then so far as I knew, there was absolutely no thinking in the direction of making a coup or seizing power. That was why, quite frankly, I decided that these actions (15) were basically provocative. Thus one of the first things to make me suspicious of the "Movement" was the justification it gave for itself.

The second announcement contained the formation of the Revolution Council, and then further declared that the Dwikora Cabinet was "demissionary"; it also made no mention whatever of the Great Leader of the Revolution. (16) So I said quite confidently that these were the ones who were making and carrying out a coup; and now they were being unmasked. On the basis of our analysis of the information contained in their announcements, we now understood, we could understand the objective of the "Movement" as being none other than a coup. Secondly, we could now separate who was friend and who foe. The foe was, first of all, Battalions 454 and 530 and the lst Tjakrabirawa Battalion, who were all involved at that point - these were the [only] Army units that we knew of as such. Now after the announcement of a Revolution Council led by Lieutenant Colonel Untung, the Air Force leadership issued a statement that the Air Force fully supported the "Movement" and the Revolution Council.(17) Various indications I had already received - first, the difficulty I had in coordinating the Air Force, second the fact that the top leadership had been "taken to safety" before the affair broke out, and third, the present statement of support - well even a fool would have been able to tell that these [the Air Force] must be classed with the foe that we had now to face.

Once we had learnt what their objectives were, and who was friend and who foe, we had to try to ensure by all possible means that there be no shooting and bloodshed. Therefore our first

(15) The word used, tindakan2, (actions), is an odi one to use to describe radio announcements.

(16) The second Untung broadcast was made at 2:00 p.m., October 1 . 'Demissionary' is a technical word used to describe the status of a defeated Government under a parliamentary system, which acts as a caretaker prior to the formation of a new Government. A singular term, by any account, to be employed in this context.

(17) This Air Force statement was signed by Omar Dhani at 9:30 a.m., October I, at Halim Airbase. It was announced over Djakarta Radio at $3: 30 \mathrm{p} . \mathrm{m}$. that same afternoon. 
move, after discovering that among the units being used by the "Movement" there were Battalions(18) from KOSTRAD itself, was [for me to] order the Brigade Commander to contact his Battalion Commanders. (It was still early in the morning). "They [Brigade HQ] sent couriers(19) to the Battalion Commanders, but the Commanders of Battalions 454 and 530 were already inside the Palace, so that they wouldn't obey my orders.(20) Now since I knew that if they were inside the Palace, actual control [over their troops] would have been turned over to their Deputies, I ordered these [last] to be contacted. Finally, the Deputy Commanders reported to me in person [langsung menghadap pada saja]. First I explained [my own position], and then asked them what their assignment was, stationed around the Palace. They answered that they had a special task, guarding the Great Leader of the Revolution, because, they said, the Council of Generals was about to launch a coup.

This [the following] is the gist of what I told them, and of the answers which the Deputy Commanders of Battalions 454 and 530 gave to my questions. I asked whether they had heard the announcements $(2 I)$ of this Revolution Council, particularly the one led by Lieutenant Colonel Untung. They said they had. (22) Then we asked them if they had ever had any knowledge of a Council of Generals launching a coup. [They said,] No. [We pointed out] that now the Revolution Council had dissolved [membubarkan](23) the Dwikora Cabinet and, furthermore, had not included the name of the Great Leader of the Revolution in the composition of the Revolution Council - indeed had not even mentioned it - and asked them: Is this a coup or isn't it? They said: Yes, they are carrying out a coup. [I said:] In that case

(18) The text is ambiguous. It is not clear whether what is meant is Battalion or Battalions.

(19) The text is ambiguous. It is not clear whether what is meant is courier or couriers.

(20) The Commanders of Battalions 454 and 530 were, respectively, Major Sukirno and Major Bambang Supeno.

(21) This is an unambiguous plural, and so places these manoeuvres in time after the $2: 00 \mathrm{p} . \mathrm{m}$. Untung broadcasts - at least according to suharto.

(22) The Indonesian text is awkward and confused: "Kemudian saja tanjakan, apakah mereka telah mendengar pengumuman2 dari Dewan Revolusi ini, terutama jang dipimpin oleh Let. Kol. Untung, mereka mendengar."

(23) This is not strictly true. The Cabinet was given "caretaker" status, but not dissolved. But doubtless Suharto felt that the niceties of parliamentary procedure would be wasted on the Company Commanders. 
you have been tricked into [thinking you are] guarding the President, but actually you have been manipulated [diperalat] into protecting the activities of this coup movement. I told them: you've been used good and proper. Now if you're really stiil loyal to the Revolution and to the Soldier's Oath, Sapta Marga, go and collect your men and come back here to report to me. If you don't, I'll be forced to take drastic action, since you've already clearly assisted a movement which is endangering our State and Revolution.

Finally the two Company Commanders agreed, and went back to their men. I also had the help of certain senior officers at that time, and also of several middle-ranking officers who came to me, and who were well acquainted with units in or individual members of the two Battalions, possibly they had been former commanding officers of the Battalions. I ordered them to take off their Generals' uniforms and go in civilian dress to explain the situation to their old subordinates. As a result, after about two hours, Battalion 530 was assembled and brought by truck to report to me. In other words, we had now managed to rescue one Battalion from this affair. Our "subtraction" [1it. "the loss"] of one Battalion (i.e. Battalion 530) was accomplished with the aid of the Commander of the Eighth Territorial Division, who was at KOSTRAD at that time. (24) In the case of Battalion 454, while the Deputy Commander of this Battalion was briefing his Company Commanders, the Battalion Commander himself came out of the Palace and resumed command of the Battalion; [this meant] that the Deputy Commander could not carry on with his briefing and explanation to the Company Commanders. So that what had been accomplished with Battalion 530 could not be carried out in the case of Battalion 454. Nonetheless I continued my efforts because I learnt - after some [time], about half a day - I got information that ... in fact there was also a courier, an adjutant of the President, who came to ask me how the situation was. (25)

I [now] knew that the President was no longer in the Palace, but in a certain place. I used this information to make another effort to make Battalion 454 realize the futility [lit. "the mistakenness" - kekeliruan] of the task they had been assigned. I was able to make contact with the Palace, with a member of the Tjakra regimental staff, and I ordered him to contact the Company Commanders and the Deputy Commander of the Battalion and bring them into the Palace. As they were assigned to protect the

(24) This was Major General Basuki Rachmat.

(25) Unluckily this vital sentence is extremely obscure in the Indonesian: "...karena saja mengetahui setelah beberapa kira2 setengah hari saja mendapat info dan djuga memang ada kurir adjudan daripada Bapak Presiden menemui saja untuk menanjakan mengenai keadaannja. 
Great Leader of the Revolution, this would convince them that he was not in the Palace, and thus their guard duty around the Palace was simply a waste of time. These officers were indeed then brought into the Palace, and once convinced that the Great Leader of the Revolution was not there, they withdrew and collected their men together in the Gedung Pemuda. (26) But apparently they were too late for the time limit I had set, and so they took off for Halim as a complete unit [keseluruhannja].

Under the circumstances the most important [installations] round the Palace were the RRI building and the Post-and-Telecommunications building. (27) These we managed to secure without any shooting, since I had in fact given [them] an ultimatum: if they did not vacate RRI by $8: 00 \mathrm{p} \cdot \mathrm{m}$., we would be compelled to take it by force with troops that we had gotten ready for that purpose. But Thanks be to God, all went [smoothly] without any use of force. (28)

My brothers, why was it that I had to sacrifice RRI to be used by them [from morning] till evening? I was well aware that if they were allowed to use the RRI to announce their activities, of course from the political point of view we would suffer great harm, especially as this would give the public the impression that there existed another authority than the authority of the Government under the leadership of the Great Leader of the Revolution. I realized the harm that we would suffer, but I was convinced that the effort to diminish their [military] strength would more [rapidly] ensure the successful settlement of the affair.

I gave top priority to avoiding bloodshed, and Thanks be to God too, since [otherwise] I could have seized the RRI by force early in the morning after the first announcement. But this would have resulted in shooting, and I still did not know the real background to this "Movement" at that time. But once the announcement of the Revolution Council and its composition had been made, their real activities were unmasked [sic], convincing us that we no longer need hesitate to take action against the September 30 th Movement, and could determine who was friend and who foe. By late afternoon [sore hari] all the [rebel] troop

(26) The Gedung Pemuda (Youth Building) is close to the Istana Merdeka, a little to the east along Djl. Merdeka Utara. It also looks out on Merdeka Square.

(27) The RRI (Djakarta Radio) building is on Djl. Merdeka Barat, on the west side of Merdeka Square. The Post-and-Telecommunications Building is on Djl. Merdeka Selatan, at the south end of the same square.

(28) The coup group went. of the air shortly after 6:00 p.m. and the RRI building was evidently in the hands of Suharto's paratroopers by 7:00 p.m. 
units - with the exception of the Tjakra who were still inside the Palace and whom we had contacted earlier, were withdrawn to Halim. This was still another indication to us that the Air Force formed the basis [sic] of the "Movement." This at least was my evaluation of the situation, [in connection] with various
facts, from morning till 6:00 p.m. (29)

Some time after 6:00 p.m., i.e. getting on for 7:00 p.m., Battalion 530 was given the task of securing among other things, the area round the National Front building, $(30)$ thus the area behind and to the South of that building. Apparently the youth organization(3I) did not realize that we had already taken over, so they came in an armed gang to occupy the National Front building. Now since this gang consisted of youths whom we still could not identify, we disarmed them and took away their weapons. It turned out that they were from the Pemuda Rakjat, and were carrying weapons from the Air Force. This we learnt from subsequent interrogations. They told us that the Air Force had distributed 3,000 arms all told, [and the Army](32) several hundred, in various parts of Djakarta. As a soldier I was naturally very concerned that 3,000 arms were in the hands of people who were not members of the Armed Forces; this already represented a force which could create disorder, especially as I had already listed the Air Force among our foes, considering their activities up to this point.

On the basis of the reports that we had received and the facts we had assembled, there seemed good reason to believe that the early morning of October 2nd would witness even more violent events: possibly a general attack or an [attempt to] take back the area around the Palace. As a soldier of course I knew that one should always anticipate the enemy rather than allow oneself to be anticipated by him. So, in order to avoid the possibility of still further trouble and confusion on October 2 nd, I decided that we must take control of Halim that very night.

(29) The Indonesian is awkward: "Ini adalah penilaian saja pada waktu itu, dengan beberapa fakta2 mulai pagi sampai dengan djam 18:00.

(30) The National Front building (the old Vice-Presidential residence) lies a little to the west of the Post-and-Telecommunications building on Djl. Merdeka Selatan.

(3I) The transition here is very abrupt, since no youth groups have been mentioned up to this point. This is also, with one exception, the sole reference to Communist-affiliated organizations in the entire speech.

(32) For this insertion, see page 175. 
My brothers, I said just now that the President had been at Halim since early morning - we had heard it from his adjutant. Actually at that time [when the adjutant appeared], the President was summoning various Army officers, i.e. General Pranoto and General Umar. All of them had already reported to me.(33) I told the adjutant in reply that he should report to the President that I had assumed provisional leadership of the Army, that I had been able to get the situation under control, and that I requested further instructions. As for the Generals who had been summoned, I forbade them to go, since, quite frankly, in my estimation Halim was the centre of the "Movement" and I did not want to lose any more Generals. So it was because of my suspicions [ketjurigaan] that I did not permit them to go.

My conclusion at that point then was that the President was secure [aman] - but whether 'secure' meant 'secure' or 'secured' [diamankan] was something I had to figure out in relation to the facts available at that time. Later on that evening, about 8:00 p.m., another courier came from the President, an adjutant of his, asking for explanations. So I explained everything to him. Then the adjutant asked me: What task does Pak Suharto give me to perform? I told him, I said: The task you must perform is to move Bapak [the President] from Halim. I then repeated it: The task you must now carry out as adjutant is to move [pindahkan] Bapak from Halim. I will be very thankful to God if you can manage to move [dapat memindahkan] Bapak from Halim. Evidently the adjutant understood what I meant [mengetahui maksud saja], and later did his utmost, since about 10:00 p.m. I got a longdistance call from Bogor that the President had already arrived there. (34) But I checked this through a Bogor man, Colonel Alex, telling him to go into the Palace; and indeed the President was already there. (35) I thank God that in regaining control of Halim it was not necessary for me to take the President out of Halim by force [mengambil dulu Bapak dengan kekerasan dari Halim], but that he was already out of Halim, so that now all that remained was seizing control of Halim.

Although I had already made plans to retake Halim, my brothers, I knew that obviously not everyone there was involved in the affair; supposing that I destroyed [menghantjurkan] Halim, who would suffer? I myself would feel that I had suffered [rugi], we all would. Therefore, the assignment I gave to the tank unit which I formed to retake Halim was: I told them strictly to avoid any shooting if they could help it, and avoid damaging

(33) General Pranoto Reksosamudro was then Third Assistant (Personnel) to the Minister/Commander of the Army. General Umar Wirahadikusumah was Commander of the Fifth (Greater Djakarta) Territorial Division.

(34) The President's week-end Palace is in Bogor, forty miles south of Djakarta.

(35) Colonel Alex is otherwise unidentified. 
airplanes and buildings, since they were our [Indonesia's] property. For this reason the counter-attack had to be carried out by night. Actually if we were to execute a conventional crushing of the "Movement," since there was a tank force all ready to go as I said before, in the framework of the Armed Forces Anniversary we had already collected together 1 tank company (22 tanks) and 1 company of armor (panzers) - if we trained all 22 tanks on Halim, I think there is no doubt that we could have destroyed it completely. But as a citizen and also as a member of the Army and partner to the other Armed Services, I did not want [anything], and especially the Air Force, to be completely destroyed since after all it was our property. So I specially selected troops who could carry out the assignment: to infiltrate and execute a night attack. Finally, at $6: 10 \mathrm{p} . \mathrm{m} .(36)_{\text {we }}$ managed to get full control of Halim without firing a shot. The one incident which did occur was when early in the morning a waterbuffalo got upset seeing the red berets of the RPKAD(37) and our people were forced to shoot it.

Thus if there was no move, there was actually no shooting. And that, my brothers, was the situation, when about 6:10 a.m. it was reported to me that the situation at Halim was now under control. There also occurred various incidents in a number of places, among others near Senajan and around the Hotel Indonesia. At the same time we managed to seize some weapons - indeed we had formed a special unit for the seizure of weapons - and we did manage to take some arms away from them.

Anyway, while we were still preparing our attack on Halim, that is, after the President/Great Leader of the Revolution had left the airbase, there was some activity - airplanes taking off. Since we had radar-equipment attached to each anti-aircraft unit, we checked up, and discovered how many planes landed and how many took off. (38) At that time there was a plane landing, a Jetstar which was supposed to pick up Pak Bandrio,(39) [though] this didn't work out, and did carry Air Marshal Sri Muljono

(36) The text has 18:10 hours. This is incorrect; compare the time of the water-buffalo story, and the time given in the first part of the succeeding paragraph.

(37) The RPKAD (Resimen Pasukan Komando Angkatan Darat) is the Army's crack commando regiment.

(38) The Indonesian is very confusing: "...ada kegiatan 2 pesawat jang naik jang sesudah kita tjek karena kita mempunjai radarnja, daripada semua satuan penangkis udara hingga kita mengetahui berapa pesawat jang naik dan berapa pesawat jang turun.

(39) Dr. Subandrio, who was at that moment in Medan. 
Herlambang. (40) And since he possibly did not know, (4I) we were forced to fire at him with our anti-aircraft guns. So, if you heard firing about 12 midnight, it was anti-aircraft guns shooting at a plane coming in to land at Halim. However the plane was not touched, and finally managed to land safely.

That same night there were also planes taking off; we tried to estimate whether they were planes going to fetch reinforcements or for subversion. It turned out later that they were carrying out an evacuation: from Halim to Jogja, and then on to Madiun, Maospati.(42)

About mid-day [siang hari], [or rather] in the morning [pagi hari], I was summoned by the President together with the Commanders of all the other Armed Services, and, from the Army, General Prapto(43) and General Mursid.(44) Actually it was early morning when I was summoned, but because I was still very busy with General Umar, organizing and taking control of the situation in the city, it was only after 1:00 p.m. that I left for Bogor. I left for Bogor about $1: 00 \mathrm{p} . \mathrm{m}$., and got there at 4:00 p.m. A meeting was immediately held. The others, i.e. the Commanders, thus the Commander of the Police; the Commander of the Navy with some of his officers; the President; Pak Leimena; from the Air Force, Commander Herlambang; Minister Tardhio(45); Minister of Trade Jusuf(46); and one other, General Sabur, as KOTI secretary, (47) had all been waiting for me for a long time.

(40) Herlambang was at the time Deputy Commander of the Air Force.

(41) The Indonesian is obscure: "karena mungkin djuga dia tidak tahu, terpaksa djuga pula di tembak...." Probably Suharto means that Herlambang did not know that the Army was trying to prevent all air traffic in and out of Halim airbase.

(42) Maospati is the large Air Force base near the city of Madiun.

(43) This is a curious mistake. General (Soe)prapto, the Second Deputy to the Minister/Commander of the Army, was one of the six generals kidnapped and killed on the morning of October l. Clearly Suharto means General Pranoto, not Prapto.

(44) General Mursid was and is First Deputy to the Minister/Commander of the Army.

(45) Minister Tardhio is Attorney-General Brigadier General R. Sutardhio.

(46) Minister Jusuf is Minister of External Trade, Brigadier General A. Jusuf.

(47) Brigadier General Sabur was and is Commander of the Tjakrabirawa Regiment, the Presidential Bodyguard. He is also secretary to the Supreme Operations Command (KOTI). 
As soon as I arrived, therefore, the meeting was immediately started. A little while after the President opened the [discussions], Air Marshal Umar [sic] Dhani and Commodore Leo [Wattimena] appeared, late, because they had had to come a long way. (48)

At this meeting the President explained that he was well aware, and understood, that this Affair was one which had to be settled immediately. It was a political affair which had to be settled immediately in the political field. For this the President [said he] required the restoration of calm and tranquillity. He gave orders that his original decision taking over direct control of the Army and appointing an Army officer, General Pranoto, as day-to-day caretaker of the Army should be put into effect. I was asked if this could be done. I answered that the President's order could [indeed] be carried out immediately; if it were announced, I would retract all the announcements I had made as temporary leader of the Army, [so that] the President and the day-to-day caretaker could perform their tasks. (49) [However] apparently the President did not want this to be done [tidak menghendaki daripada pelaksanaan tsb.], but wished me to continue carrying out the restoration of security and order. Since there was some question about the status of his [original] order, $(50)$ the President finally gave a radio address explaining the existence of this order and affirming the task I had been given, as KOSTRAD Commander, to restore order and security. These are the facts up to October 2 .

The tasks given me by His Excellency the President were: first, to make every effort to avoid bloodshed, especially between the Army and the Air Force. I told him that this could be guaranteed and carried out. Second, I was to secure all arms in the hands of people who were not members of the Armed Forces. Last night in my report,(51) I explained that there were about

(48) Evidently from Central Java.

(49) The Indonesian is a little obscure: "...perintah daripada Bapak Presiden bisa dilaksanakan segera bilamana diumumkan saja akan mentjabut segala pengumuman saja sebagai pimpinan sementara A.D. jang kemudian baik Presiden, caretaker harian bisa melakukan tugasnja.

(50) The Indonesian is rather obscure: "Karena dasar dari perintah beliau ada tidak ada achirnja diadakan pidato...."

(51) Again an obscurity. The Indonesian is: "Tadi malam laporan saja, saja djelaskan...." The implication is that Suharto made a report to Soekarno on October 1 . But it is possible that thjs is an aside and suharto is referring to a report he made on October 14, i.e. the night before his present speech to the National Front officials. 
3,000 arms from the Air Force, and about 200 from the Army, which had been removed by the followers of the September 30 th Movement. These then were the two tasks which I was given: 1) fighting, clashes between one Armed Service and another, particularly between the Army and the Air Force, must be prevented at all costs. This I said we could manage. 2) We must take back [all] arms in the hands of people outside the Armed Forces. I said I could guarantee this too, but it would take some time, since we did not know precisely where these arms were.

My brothers, after we had reported on October $1,(52)$ we naturally did our best to discover the fate of our kidnapped Generals. So on the evening of October 1, - the eve of October 2 - our troops, who had carried out a successful manoeuvre without any shots being fired, were withdrawn, precisely in order to avoid shooting between the Air Force and ourselves. (53) I gave orders to look for scouts, (54) [to hunt down] clues as to the fate of our Generals. By God's Grace, that very night we already received some indications -- there were some points that we got to know, on the basis of reports from people who knew what had happened. That same night too, moves were made to hunt for them; and finally we found the place of execution of our Generals. It was in a spot at the edge of the Lubang Buaja (Crocodile Hole) district which is part of the Halim Air Base. Nearby there was a training-ground, with tents set up by the Air Force for training members of the Pemuda Rakjat and Gerwani. They had already held about three training-courses there.

On October 3 , I gave instructions that it should be understood that the exhumations of the bodies would take place only at my orders. On the morning of october 4 we exhumed the bodies. It proved to be true that the bodies of all 6 Generals and one officer, the adjutant of the Minister/Chief of Staff of the

(52) See previous footnote. It is not clear to whom suharto reported if it was not Soekarno.

(53) This is further confirmation that Halim did not fall to Suharto till the morning of october 2. But the syntax is exceedingly awkward.

(54) The Indonesian is: "...saja perintahkan mentjari penjelusur, dimana bekas 2 daripada nasib daripada Djenderal2 kita." Penjelusur would mean "slider," which makes no sense. Penjelusup means "scout" or "infiltrator." The sense is then somewhat improved, although one still requires a verb between penjelusup and dimana, and it is odd that suharto would give orders to look for scouts. The best solution would be menjelusup, with the sense then being: "I gave orders to look for, to scout out clues as to the fate..." But this would mean two separate misprints in one word. 
Armed Forces, (55) had been put into a dry well. It appears that [the executioners] really thought and believed that the bodies would not be discovered, since the well was closed and the hole at the top was filled in solid, so that, as it were, nothing would show. However, with the indications that we had we were finally able to find this well, as has been reported in the newspapers. We had to do it [this way] because of the President's instructions, among other things, to avoid clashes between the Army and the Air Force. On the other hand, it would obviously be very hard and difficult to control our boys' fury [once they knew what had happened], even though the President had given his second radio address in which he explained that he himself was safe and held the top leadership, (56) and that furthermore the Air Force was not involved in the affair [so that] shooting between the Air Force and the Army must be avoided. (57)

Finally, in order to put a curb [mengekang] on actions which might get out of control, I felt compelled to issue a statement on the spot, the contents of which confirmed (58) the President's [declaration] that the Air Force was not involved, but [noted] that on the basis of the [known] facts it was impossible that some Air Force elements were not involved. Therefore I unged the Air Force to take immediate action against those elements involved in the affair. My aim was to keep a tight rein on undisciplined acts by our own boys, and also to induce the Air Force to take a firm attitude, clearly distinguishing between right and wrong. (59) Thanks be to God, we were able to control

(55) The Minister/Chief of Staff of the Armed Forces was and is General Abdul Haris Vasution. His adjutant was Pierre Tendean.

(56) Suharto says: "memimpin tapuk pimpinan" - lead the top leadership. This is a clear mistake for memegang tapuk pimpinan" - held the top leadership.

(57) The Indonesian syntax is very odd: "...bahwa AURI tidak terlibat dalam soal ini harus didjauhkan tembak merembak antara AURI dan AD.

(58) The Indonesian word translated by "confirmed" is actually membenarkan, which literally means "declares to be correct" with a certain overtone of superiority on the part of the declarer.

(59) The Indonesian: "...memisahkan mana jang salah dan mana jang benar," can mean ristinguish between right and wrong," but it can also mean "distinguish between those who are in the right and those who are in the wrong." 
our boys, so that there were no undisciplined acts of revenge,
etc.

My brothers, you can all imagine the fury of a soldier once he learned what had happened. Perhaps an officer could be controlled, but an ordinary soldier would be very hard to restrain. But by explanations and briefings in accordance with the Great leader of the Revolution's wish that we be magnanimous, we managed to convince our men to be magnanimous too and [abandon] all desire for revenge towards anyone. This was especially [facilitated] once we discovered that the Air Force as an organ [of state] was not involved, only some Air Force elements. [But] all these elements had to be hunted down, and [so] we left this up to the Air Force itself; there was no need for us to intervene to settle the Air Force's affairs ourselves. (61)

Such then is my explanation of the facts and the results of my effort to perform the tasks given me by the President. This included bringing the Army and Air Force together, which I did by summoning them and dispelling thein fear-psychosis [lit.- angpsyhos!] towards the Army. Since I knew many Air Force officers personally, I summoned them one by one, and also in groups, so that eventually we were able to restore a [normal] atmosphere and eliminate mutual suspicion between the officers of the two forces. Then to paralyze [melumpuhkan] the armed strength [of the coup group] ... there were various units which had fled, but finally they too surrendered. In their flight they reached Bekasi, they reached Bekasi on october I, and on October 2 they assembled and surrendered. (62)

Basically all the troops which had originally been involved, especially Battalions 454 and 530, were in our hands; whereupon it became clear that the men in these units had been swayed by

(60) The Indonesian: "Sjukur alhamdulillah bisa mengendalikan daripada anak2 kita jang liar baik untuk membalas dendam dllnja adalah tidak ada," is in many respects obscure. The above translation is a hopeful approximation to the General's meaning.

(61) The last word of the sentence, sendiri, is ambiguous. It may mean "ourselves" as in the translation above. It may may however refer to the Air Force: in which case the last phrase should be translated: "to settle the internal affairs of the Air Force."

(62) The Indonesian is very eccentric: "Untuk melumpuhkan kekuatan jang bersendjata, ada beberapa pasukan jang tadinja melarikan diri akan tetapi djuga achirnja mereka menjerahkan diri waktu melarikan diri sampai Bekasi pada tg. I sampai Bekasi dan tg. 2nja mereka mengumpulkan dan menjerahkan kembali." Bekasi is a small town about twenty miles east of Djakarta. 
irresponsible elements. We also managed to capture the ringleaders of this affair, all, that is, except General Supardjo, who still has not been arrested. [This being so], it is now clearly the duty of the public and the mass organizations to help ensure General Supardjo's immediate apprehension. We still do not know the exact quantity of the arms that were distributed, although we have already confiscated several hundreds. But it is clear that there are still a great many in [unauthorized hands], and we shall have to keep up a constant effort to regain them as quickly as possible so that they do not remain in the hands of people outside the Armed Forces. This is my area of responsibility - restoring security. As for the political field, perhaps Pak Bandrio already gave an explanation yesterday. I am simply giving the facts to the Government, particularly to the President, to help settle matters in the political field, since the President has already decided: I appoint you to restore security and order; as for a political settlement, I shall settle that myself.

In this matter then my duty has been to restore order and security, and I have done this as far as possible. Thanks be to God, I have experienced [rasakan] the help of the progressive and revolutionary People, so that our efforts to regain distributed arms and arrest the ringleaders of this affair, especially from the Army, have gone ahead very successfully. (63)

Such is the explanation that I felt I should give. I have given you the facts, my brothers. It is up to you to make your own evaluation with regard to the affair itself: Was it really simply an internal Army affair, or was it politically-connected [apakah peristiwa itu hanja chusus peristiwa didalam AD ataukah peristiwa jang menjangkut dalam bidang politik]? for this, General Sutjipto will give you the facts which connect this affair with political questions. (64) I ask you to give General sutjipto the time to give you further clarifications.

Thank you.

(63) The Indonesian is obscure: "...dapat saja rasakan sehingga pengambilan sendjata tsb. maupun penangkapan terhadap pelaku2 daripada peristiwa baik daripada AD pada chususnja dapat berhasil dengan sebaik2nja."

(64) Again the Indonesian is obscure and contorted: "Untuk itu maka Djenderal Sutjipto akan memberikan fakta2 jang menjangkut peristiwa tsb. jang berhubungan dengan soal 2 politik. 
4. Speech of Caretaker Commander of the 72nd Military Resort (Jogjakarta - Surakarta), Colonel Widodo.

The translation is based on the Indonesian language text in Kedaulatan Rakjat, October 8. Col. Widodo was appointed by General Surjosumpeno, Divisional Commander of the VIIth Military Territorial Command (Central Java), as temporary caretaker Commander of the 72 nd Military Resort in the place of Col. Katamso, who had been kidnapped and (as it later turned out) murdered by the Seotember 30 th Movement forces. Col. Widodo, whose appointment took effect on Dctober 5 , was thus the Army High Command's agent for restoring control in the critical region around the old royal capitals of Surakarta and Jogjakarta. The following is his first major address issued to the public].

As you all know, since October 5, 1965, I, Colonel Nidodo, Fourth Assistant to the Chief of Staff of the VIIth Military Territorial Command (Diponegoro), on the orders of the Commander of the VIIth Military Territorial Command (Diponegoro), 3rigadier General Surjosumpeno, have assumed temporarv leadership of the 72 nd Military Resort.

The basic tasks that I have been given by the Commander are: to restore the entire battle-order of the 72 nd Military Resort to the fold of the VIIth Military Territorial Command (Diponegoro), and to locate and restore Colonel Katamso and Lieutenant Colonel Sugijono to their original posts - that is, to the posts they held prior to the so-called September 30 th Movement.

I am thankful to say that the discharge of this task is proceeding verv successfully thanks to the Soldiers, the N.C.O.'s and the officers of the entire battle-order of the 72 nd Military Resort, who, genuinely inspired bv the spirit of the Sapta Marga and the Soldier's Oath, Pantịasila and Nasakom, honor everv order and line laid down by their Supreme Commander, Bung, Karno, whom we all love and whom we all obev.

I am firmly convinced that mv task will continue to have the support and understanding of all members of the T.N.I. within the hierarchy of the 72 nd Military Resort, God willing [Insja AIlah]. Amen.

In accordance with the wish of the Supreme Commander on the conditions for the unity of the Armed Forces and the Peodle, as laid down in Manipol ".... the Indonesian Armed Forces are not an Army separate from the People," -. and still more firmly in TAKARI", ".... Our Armed Services will become an invincible force if they are at one with the People," -- I am fully convinced that I shall receive sincere cooderation from the entire Mass of the People in this area, who have Nasakom as their axis and spirit. 
We all know that the present situation -- we feel that it is something which really and truly demands the attention of us all. We must realize that above all we must set aside our own individual interests and the interests of our group for the sake of the higher interests of the State, the People and the Revolution.

I therefore hope for the fullest understanding from the whole community -- that we must all take a firm attitude, side with the Indonesian Revolution, and remain unreservedly obedient to the high guidance and leadership of Bung Karno.

In carrying out the task of restoring the original [pre-October 1] situation, which I have received from the Commander of the VIIth Military Territorial Command (Diponegoro), all of us who together are following the track of the Indonesian Revolution will certainly be able to march in step, since this task of restoring the situation is a prime condition, even an essential condition for carrying out the vital national task of the moment, i.e. implementing Dwikora.

In this connection I think I should stress that I have held extremely important talks with local notables [exponen2 daerah], with the Consultative Regional Leadership Body of the Special Region of Jogjakarta - - and as we all know, this is a very broad forum.

In these very important talks, some very important conclusions were reached, [most particularly] that all groups within the Consultative Regional Leadership Body of the Special Region of Jogjakarta unanimously agreed to use all their influence to restore the situation.

I appeal therefore to all levels of the Community, to all the progressive and revolutionary People, who have Nasakom as their axis and their spirit, to obey all [their] leaders, and all instructions from existing leaders of the community, via the National Front, via the Political Parties and the Mass Organizations. Obey their instructions!

We must be on the alert, we must not doubt for a moment that Nekolim will take advantage of any internal problem among ourselves. Be sure that the path of Unity is the best path, since Unity, progressive revolutionary Unity, with Nasakom as its axis and spirit, is the teaching of the Great Leader of our Revolution.

As temporary Commander of the 72nd Military Resort, and also acting as PEPELRADA2 supervisor and coordinator in the areas of the Special Region of Jogjakarta and the former Residencies of Kedu and Surakarta, I appeal for the entire People's understanding on various matters, as follows: 
a) Avoid and refrain from any attitudes or actions which might give rise to divisions among ourselves.

b) Remain obedient to the President/Suoreme Commander of the Armed Forces/Great Leader of the Revolution Bung Karno.

c) Assist the implementation of the restoration of the situation prior to the affair of the so-called september 30 th Movement, because not assisting in this task is contrary to the lines laid down in the Messages of the President/Supreme Commander of the Armed Forces/Great Leader of the Revolution Bung Karno.

d) The whole community is strongly urged to obey the directives of the authorities with regard to meetings and other such matters, and also for the time being to refrain from organizing demonstrations and parades, as well as sticking up placards, all of which can easily exacerbate the present critical situation.

e) Let us all heighten our devotion to the One God, and let us beseech the Supreme Essence, Allah the Almighty and All-Merciful, to bestor His Guidance and Blessing on us all.

Finally let us all together bow our heads for a moment in memory of the souls of those Heroes of the Indonesian Revolution, General (Dosthumous) Ahmad Yani, Lieutenant General (posthumous) Suprapto, Lieutenant General (posthumous) S. Parman, Lieutenant General (posthumous) Harjono, Major General (Dosthumous) Sutojo Siswomihardjo, Major General (posthumous) Pandjaitan, and Captain (posthumous) Pier [sic] Tendean; may Allah, the Almighty and All-Merciful, forgive their shortcomings; may their souls be granted a place at God's side; and mav the families they have left behind find strength and firmness of faith, God willing. Amen.

\section{NOTES}

1. TAKARI is an acronvm for Tahun Berdikari (A Year of Standing on Our Own Feet), President Sukarno's August 17th speech for 1965 .

2. PEPELRADA is an abbreviation for Penguasa Pelaksanaan Dwikora Daerah (Regional Authority for the Implementation of Diwikora, or as some sources less accuratelv have it, Regional Dwikora Administrator). The Pepelrada were set up bv Presidential Decision No. 52/KOTI/ 1964 to help coordinate and direct Confrontation activities. Generally soeaking the local military were desinnated as the Pepelrada. The Presidential Decision gave the Penelrada the Dower to act in a "quasimartial las" fashion under certain circumstances. 
5. Statement of General Nasution of November 12. [This translation is based on the Indonesian text to be found in Berita Yudha of November 15. The statement was made at an informal meeting with a delegation of the Central Action Unit of Indonesian Students at Armed Forces Staff Headquarters. The statement is one of the earliest public assessments of the october 1 Affair and its epilogue by the General.]

The General stated that we must not only completelv destroy the executants of the "Seotember 30 th Movement", but also its masterminds and their supporters.

He declared that the principal executants of the "September 30th Movement" had indeed turned out to be prominent veterans of the terror of the Madiun Affair. Since after [that affair] they had been permitted to operate, and had even been given opportunities to step up their activities, the results were rot we can see todav.

Three times now thev have tried to kill me, the General averred. They savagelv butchered our Generals and middlelevel officers in the twinkling of an eve; civilian victims lie sprawled everv'where; they even tried to overthrow the state and the revolution. For this reason there must be no more hesitation arginst the executants, supporters and es necially the masterminds of the "September 30 th Movement." They should not and can not be siven any more opportunities, and their activities should no longer be protected by law. They must be immediately smashed; especially their masterminds and dangerous supporters must be isolated at once. Since they have committed treason, and distorted the course of our state and revolution, they must be destroyed and quarantined from all activities in our fatherland. If thev are still permitted to enjov freedom of movement, the safetv of the state would certainly constantly be menaced.

After explaining that there had never been any so-called "Council of Generals", as bruited about in their cruel slanders concerning the Armed Forces, General Nasution warned the students not to be deceived but to be constantly on the alert for the wicked slanders which recently have been so frequentiy hurled against us.

How easy to submit "documents," which they forged themselves, as slanderous evidence against the Armed Forces -which finally resulted in the national tragedy which has brought sorrow to us all.

Reacting to the question of the P.K.I., General Nasution stressed that it was not because we are anti-communist that we must annihilate the P.K.I. But proofs and undeniable facts, which have become widely known to the entire community, 
demonstrate that the P.K.I. has clearly betrayed the state and nation. They have clearly performed counter-revolutionary actions, they have clearly violated the basic [principles] of our state, and therefore we are obliged and dutybound to wipe them from the soil of Indonesia.

We must indeed be united. But must we, just because this group is Communist, although it has committed murder, torture, terror and treason against our state and government, still embrace it? This question, put by General Nasution to the student leaders, was immediately answered: "No!"

Finally General Nasution expressed his satisfaction that the students were now able to consolidate their unity, urged on by a sense of awareness and mutual responsibility towards the state and the revolution; and that they were united because they shared a common destiny and a common struggle in facing the dangers of "Gestapu" which is menacing student life. 


\section{STATEMENTS BY THE INDONESIAN COMMUNIST PARTY}

1. Editorial Appearing in the October 2 Edition of the Indonesian Communist Party Newspaper. Apparently Issued Late on the Afternoon of October 1 .

The following translation is based exclusively on the Indonesian text found in Harian Rakjat of October 2. While the precise times at which this editorial was written and the paper actually printed and then issued can not be determined, it should be noted that both the normal Friday publishing practices of Harian Rakjat and the internal evidence of the issue indicate that the paper went to press in the late afternoon of October 1. This must have been shortly following receipt of news of the President's afternoon appointment of Major General Pranoto as caretaker of the Army -- for this news appears in Harian Rakjat as a "Stop Press" item.]

\section{THE SEPTEMBER 3OTH MOVEMENT}

It has happened that on the 30 th of september measures were taken to safeguard President Sukarno and the Republic of Indonesia from a coup by a so-called Council of Generals. According to what has been announced by the September 30 th Movement, which is headed by Lt. Col. Untung of a Tjakrabirawa battalion, action taken to preserve President Sukarno and the Republic of Indonesia from the coup by the Council of Generals is patriotic and revolutionary.

Whatever the justification that may have been used by the Council of Generals in its attempt, the staging of a coup is a condemnable and counter-revolutionary act.

We the People fully comprehend what Lt. Col. Untung has asserted in carrying out his patriotic movement.

But however the case may be, this is an internal Army affair. On the other hand, we the People, who are conscious of the policy and duties of the revolution, are convinced of the correctness of the action taken by the September 30 th Movement to preserve the revolution and the People.

The sympathy and support of the People is surely on the side of the September 30 th Movement. We call on the People to intensify their vigilance and be prepared to confront ali eventualities. 
2. Statement of the Leadership of the East Java Communist Youth Organization. Issued on October 1 .

The translation of this statement of the East Java branch of the Pemuda Rakjat (the Indonesian Communist Party's Youth

Organization) is based on the Indonesian text given in Berita Yudha, October 7, 1965.]

Leadership of the Major Region (East Java) People's Youth, Djl. Kaliasin 139, Surabaja.

Statement supporting the "September 30 th Movement" No. $156 / \mathrm{V} / \mathrm{PDB} / 65$.

In connection with the occurrence of a September 30 th Movement under the leadership of Lieutenant Colonel Untung to safeguard the Indonesian Revolution and Bung Karno, and in relation to the Revolutionary situation which has enraged the counter-revolutionaries into forming a so-called "Council of Generals" to carry out a coup d'etat [against] the Government of the Republic of Indonesia, in the name of the 750,000 members of the People's Youth for the whole of East Java, we declare our fullest support for, and stand behind the September 30 th Movement in forming Indonesian Revolution Councils down to the regions.

We instruct all Organization Leadership Bodies as well as the entire membership of the East Java People's Youth to sharpen their vigilance, heighten their support for Youth Unity on the basis of the Nasakom axis and carry out the Five Charms of the Revolution, in order to continue to crush American imperialism, "Malaysia," village devils, city devils, modern revisionism and other internal counter-revolutionary elements.

Surabaja, October $1,1965$. Leadership of the Major Region

(East Java) People's Youth, signed, Tjap S. Gijo.

(This statement has been sent to the Honorable Indonesian Revolution Council in Djakarta. Copies have been forwarded to the National Council of the People's Youth in Djakarta, and to the Press and Radio). 
3. Statement of the North Sumatra Committee of the Indonesian Communist Party. Issued on October 4.

The translation is based on the Indonesian text of the Press Statement of Djalaludin Jusuf Nasution, First Secretary of the North Sumatra Major Regional Committee of the Indonesian Communist Party (P.K.I.) on October 4, 1965, as contained in the Medan daily, Harian Harapan, for October 5, 1965.]

I would like to say first of all that it would be inappropriate to issue a hasty opinion in assessing an event as serious as the September 30 th Affair, especially for us here, in an area so distant from the scene of that Affair. The important thing is to take an attitude of sincerely joining in helping to settle the Affair by ensuring the victory of the demands of the Revolution in accordance with Bung Karno's line in Manipol.

As we know from RRI broadcasts, since Lieutenant Colonel Untung's announcement of a September 30 th Movement, claiming to aim, among other things, at safeguarding President Sukarno and the Republic of Indonesia from the danger of a coup by a Council of Generals, and carrying out a purge within the body of the Army, a series of events have transpired in a short time, the most important of which have been:

1. On October 1, 1965, the President/Supreme Commander of the Armed Forces/ Great Leader of the Revolution Bung Karno issued an order as stated in his first Message of October 2.

2. Also on October 1, Major General Suharto took over temporary leadership of the Army to overcome the September 30 th Movement.

3. On October 2, the President/Supreme Commander of the Armed Forces/ Great Leader of the Revolution Bung Karno in his first Message declared that leadership of the Army was directly in his hands.

4. On October 3, the President/Supreme Commander of the Armed Forces/ Great Leader of the Revolution Bung Karno issued his second Message, saying, among other things, that accusations that the Indonesian Air Force was involved in the September 30 th Affair were not true.

From this chain of events, and in accordance with Bung Karno's own affirmations in his Messages, namely that Bung Karno continued to hold the top leadership of the Indonesian State, Government and Revolution,

It is therefore my opinion that for every revolutionary person who truly loves the Republic of Indonesia and the Great Leader of the Revolution, Bung Karno, the only guides [pegangan] for helping to settle the September 30 th Affair are the Messages 
and the policy of the President/Supreme Commander of the Armed Forces/ Great Leader of the Revolution Bung Karno.

Giving interpretations conflicting with the lines laid down by Bung Karno, let alone interpretations which are insinuating and provocative, will not only give rise to new difficulties but may also mean opposing the policy of the Great Leader of the Revolution Bung Karno.

I call on all cadres, candidate-members and members of the P.K.I., as well as all the progressive masses in this area, constantly to heighten their vigilance and also constantly to advance the revolutionary offensive in all fields and above all to make a success of Dwikora.

4. Statement of the Jogjakarta Regional Committee of the Indonesian Communist Party. Issued on October 5. The translation is based on the Javanese text found in the Jogjakarta daily, Ariwarti Waspada, of October 6, 1965. The October lst "Instruction" of the Central Java PKI referred to in the text did not appear in earlier editions of Ariwarti Waspada.]

The September 30, 1965, Affair clearly must be regarded with great seriousness by all levels of the community so that the policy of His Excellency, President/Great Leader of the Revolution/Bung Karno for settling this Affair can go forward smoothly and as successfully as possible in order to ensure the victory of our national revolution.

The Jogjakarta Regional Committee of the P.K.I. is firmly of the opinion, as [expressed in] the Instruction of the Central Java Committee of the P.K.I., dated October 1, 1965, that the September 30th, 1965, Affair is an internal Army problem, and therefore that the Party has no part in it.

At present His Excellency the President has already announced his policy. It is now the duty of the revolutionary forces to help settle [things] as successfully as possible.

But it is extremely regrettable that after the ceremony formalizing the take-over of the former "Jefferson" Building by the National Front of the Special Region of Jogjakarta on October 4, 1965, at about 17:00 hours, a gang of H.M.I. people carried out anarchic actions reminiscent of the practices of the D.I./T.I.I., tearing down the signboard of the Jogjakarta Regional Committee of the P.K.I., breaking glass panes in the door, burning posters for the C.G.M.I. Congress, uprooting the signboards of the People's Youth, Resort Committees and Gerwani, throwing stones at the Pembaruan book-store and uttering threatening yelis. 
These actions, which must be condemned, clearly obstruct the smooth working of the policy of His Excellency President Sukarno! In connection with this, the Jogjakarta Regional Committee of the P.K.I. declares:

1. Once again, all members and candidate members of the P.K.I. (Jogjakarta Region) are urged to hold firmly to the October 1, 1965, Instruction of the Major Region Committee.

2. [The Committee] strongly condemns the H.M.I. gang which is disturbing the policy of His Excellency the President, which must be helped by [maintaining] calmness.

3. [The Committee] calls on all revolutionary forces which have Nasakom as their axis and spirit to close their ranks still more firmly and help His Excellency President Sukarno in settling this very serious problem to ensure the victory of our national revolution.

\author{
Long Live Bung Karno! \\ Long Live Revolutionary Unity! \\ Long Live the Republic of Indonesia!
}

5. Statement of the Political Bureau of the Central Committee of the Indonesian Communist Party. Issued on October 5. The translation is based on the identical Indonesian and Javanese texts of this statement appearing in the Jogjakarta daily, Ariwarti Waspada, for October 8 and 9.]

The Indonesian Communist Party Supports the Message of President Sukarno, Supreme Commander of the Armed Forces of the Republic of Indonesia, on settling the problem of the September 30 th Movement.

Having carefully studied the Message of President Sukarno, Supreme Commander of the Armed Forces of the Republic of Indonesia and Great Leader of the Revolution, the Political Bureau of the Central Committee of the Indonesian Communist Party states that it fully supports this Message, and calls on all Committees of the P.K.I., all members and sympathizers of the P.K.I. and all revolutionary mass organizations led by P.K.I. cadres to help carry out the Message of President Sukarno, Supreme Commander of the Armed Forces of the Republic of Indonesia and Great Leader of the Revolution.

With regard to the September 30 th Movement, the Central Committee of the P.K.I. considers it to be an internal problem of the Army and the P.K.I. does not involve itself in it [tidak mentjampurinja]. 
With regard to the names of members of the P.K.I. included in the list of the Indonesian Revolution Council, it can be stated, as a consequence of questions put to the members concerned, that these members were neither informed beforehand nor asked for their permission.

The Central Committee of the P.K.I. calls on the whole People to continue to heighten their vigilance, to continue to strengthen the National United Front, the Nasakom Axis and the Nasakom Spirit in putting into practice the Five Charms of the Revolution, in carrying out Dwikora to crush the joint British-U.S. Project "Malaysia," and to continue the anti-Nekolim struggle in general.

\author{
Djakarta, October 5, 1965. \\ Political Bureau, Central Committee \\ of the P.K.I.
}

6. Appeal of the Central Java Committee of the Indonesian Communist Party. Issued on October 7 or 8 . The translation is derived from the Indonesian text presented in the Semarang daily, Gema Massa, for October 9, 1965. Although no date is given for the statement, the fact that the Cabinet meeting referred to in the text took place on 0ctober 6 and the fact that the paper carrying the statement is dated October 9 makes it probable that the statement was issued on 0ctober 7 or October 8. The headlines of the news item carrying the statement are given at the outset.]

\author{
Appeal of the Central Java PKI Committee \\ Faithfully Implement and Secure President \\ Sukarno's Line for Settling the Problem \\ of the "September 30th Movement"
}

In order to carry out the Statement of the Political Bureau of the Central Committee of the P.K.I. with regard to settling the problem of the "September 30 th Movement" in accordance with the Message of His Excellency the President and the clarification [given by] His Excellency the President in the plenary session of the Dwikora Cabinet just held in the Bogor Palace, all cadres, members and sympathizers of the P.K.I. throughout Central Java are instructed:

1. To help create a calm and orderly atmosphere in the regions as a condition for smoothing the way to a political solution to the problem of the "September 30th Movement" as set forth in the Message of His Excellency the President/Supreme Commander of the Indonesian Armed Forces/Great Leader of the Revolution Bung Karno. 
2. To implement faithfully the directive of His Excellency the President in the plenary session of the Dwikora Cabinet, that we not lose our heads, that we not be ruled by passions [or] by accusations and counter-accusations which serve to sow discord among us, because this is precisely what Nekolim desire and are waiting for.

3. To safeguard and continuously to strengthen National Revolutionary Unity based on the Nasakom axis and spirit, to avoid physical clashes which might arise among fellow revolutionary forces in the regions, to reintensify the implementation of the Pantja Azimat Revolusi [the five charms of the revolution] and to ensure the victory of Dwikora by crushing the neo-colonialist project "Malaysia."

$$
\begin{aligned}
& \text { Long Live Nasakom! } \\
& \text { Long Live Manipol! } \\
& \text { Ever Onward, Never Retreat! }
\end{aligned}
$$
P.K.I.

Such is the appeal of the Central Java Committee of the

7. Policy Guideline Issued by the Acting Governor of Central Java in mid-october.

The text is based on a Javanese language original contained in Ariwarti Waspada (Jogjakarta) of October 16. It should be noted that Acting Governor Sujono Atmo was, if not officially a PKI member, certainly very close to the Party indeed.]

The Acting Governor of Central Java, Sujono Atmo, recently issued a policy guideline of the Provincial Government to [all] Bupatis/Mayors/Regional Heads and Department Chiefs as well as assistants/liaison officials of the Governor within the territory of Central Java, the contents of which are as follows:

1. The guidelines or pillars of the policy of the Provincial Government are:

a. The Message of His Excellency the President of October 2,1965 ;

b. The Message of His Excellency the President of October 3,1965 ;

c. The briefing given by His Excellency the President in the presence of the commanders of Greater Djakarta combat units;

d. The Instruction of His Honor the Minister of the Interior issued over the radio, and the appeal of the Central Java Pantjatunggal of October 2, 1965; 
e. The decisions of the plenary session of the Dwikora Cabinet in the Bogor Palace on October 6, 1965, the essence of which:

1. Condemned the murderous acts committed against 6 Senior Officers and [1] Junior Officer of the Army, who have now been declared Heroes of the Revolution by the President/Supreme Commander of the Armed Forces and the whole Indonesian People.

2. Disapproved the actions of the Revolution Council.

3. [Declared] the need for a calm and disciplined atmosphere to settle the September 30 th Affair.

II. It is therefore hereby instructed:

1. That Bupatis/Mayors/Regional Heads and Department Chiefs harmonize their attitudes and perform their duties in accordance with the essence of the abovementioned Messages and Decisions.

2. That day-to-day duties be carried on as usual and that Bupatis/Mayors/Regional Heads and Department Chiefs preserve discipline and calm in connection with their work and also do their utmost to try to heighten vigilance with regard to Nekolim provocations.

3. That they hold frequent consultations and deliberations with the National Front in carrying out the Messages of the President/Supreme Leader of the National Front.

4. That they assist the efforts undertaken by the Armed Forces of Central Java to restore security and order.

5. Since the Revolution Council is not correct, that Bupatis/Mayors and Regional Heads throughout Central Java see that such elements are dissolved where they exist.

6 . That they closely coordinate their activities together with the Pantja Tunggal, each in their own areas.

7. That they make sure that the wheels of the economy turn as usual and make every effort to lighten the burdens of the People.

Thus the appeal/instruction of the Acting Governor of Central Java, Sujono Atmo. 
8. Interview of Second Deputy Chairman of the P.K.I. Njoto with Asahi Shimbun, December 2. [TOKyO ASAHI EVENING NEWS in English December 2, 1965-- Verbatim transcript of the written question and answer exchange between ASAHI SHIMBUN Djakarta correspondents, Risuke Hayashi and Takehiko Tadokoro, and Second Deputy Chairman Njoto of the Indonesian Communist Party.]

[Text] Question: Do you think the 30 September Movement is a counterrevolution to the Indonesian revolution, as the army charges?

Njoto: If we talk about revolution and counterrevolution, there must first be an answer to the question: Revolution by whom and against whom? In Indonesia, one may say, people all agree that the issue is: Was Untung's premise about there being a "council of generals" that wanted to carry out a coup d'etat true? If there is not a "council of generals" then Untung was wrong, or it may be said, counterrevolutionary. If there is a "council of generals" then Untung was not wrong, or it may be said, revolutionary.

Question: How about the foreign influence on the movement?

Njoto: I don't know anything about foreign influence on the 30 September Movement. As you gentlemen know, the PKI believes that it is an internal matter of the army. If you ask was there any foreign influence on the 30 September Movement it means the same thing as asking, is there any foreign influence in the army?

Question: What do you think about the activities of Nekolim, especially the activities of the American CIA before this movement? How about the connections between this movement and CIA?

Njoto: Nekolim activities, in particular the CIA of the United States, were there not only before, but also during and after the 30 September affair. It is not very easy to see CIA activities because, first of all, CIA works in a subversive way; and second, because in Indonesia nowadays all persons state they are anti-CIA. CIA agents themselves shout they are anti-CIA. Certainly, CIA is not like the "good fairy" in children's stories with the result that, while things are happening in Indonesia as today, they only sit doing nothing, idly looking on. It is certain there are connections between CIA and the prolog and epilog of 30 september. I cannot yet say whether CIA stood on that side or this side. 
Question: What do you think about the reports or announcements which relate the communist party with this movement and the murders of seven generals?

Njoto: Concerning the connections between the PKI and the 30 September Movement and the murders of seven generals, the PKI leadership, as was the case with most others, knew nothing of either of these until after they happened. At that time, I, together with First Deputy Premier Dr. Subandrio and a number of army, navy, air force, and police generals, was on a journey in Sumatra for the state. We heard about the 30 September affair together when we were in Pangkalan Brandan, North Sumatra, and we were all shocked in the same way.

Question: What do you think of President Sukarno's announcement that the 30 September Movement was not just within the army, but also a problem of the nation?

Njoto: President Sukarno on one side said that "there have taken place events in the army and in the Tjakrabirawa Regiment (Presidential Guard Regiment), and on the other side he said it is a "national question." The PKI feels the same. If it is said that it is an internal matter of the army, this is not meant to say that it is not a national question. Or that it cannot become a national question. The PKI has never believed that. Neither President Sukarno's opinion nor the PKI's opinion which is the same is a contradiction in terminis.

Question: What do you think about the arming of your party which many people saw? Especially, how about the Pemuda Rakjat?

Njoto: Indonesians now getting military training, inclusive of the use of several kinds of conventional weapons, are not restricted to communists and members of the Pemuda Rakjat; the four forces--army, navy, air force, and police force--are all training masses of citizens and youths. As you know in Indonesia now, in facing "Malaysia," about 22 million volunteers have been organized and, if I am not wrong, it is President Sukarno's plan that all of them must have military training.

Question: Do you still support President Sukarno and his Nasakom regime?

Njoto: This question should better be asked of the ones who, since 1 October, have ignored President Sukarno's commands. In the statement of its Politburo both on 5 and 10 October and also in actual deeds, the PKI fully backs the President's commands. I do not understand very well what you mean by "Nasakom regime," formerly, now, or in the future. If you mean the first two, the "former one" or the "present one," not one of them has ever existed. President Sukarno says that a Nasakom government continues to be his aspiration. 
Question: What do you think about the activities of the army or the religious parties urging that the communist party should be outlawed or prohibited?

Njoto: I don't think that the whole army and every religious party is urging the dissolution of the PKI. This is not an "effort to . . . . . . . ."* because I am only--to borrow an expression used by Gen. Ibrahim Adjie--stating facts. If the whole army was already anti-PKI, then there would not be a necessity for "Koti Instruction No. 22" on the "cleaning-up." As you know, for almost two months, the left side of the frontpage up to the right side of the backpage has demanded the dissolution of the PKI. But President Sukarno has not dissolved the PKI. He has even retained the Nasakom theory. This is indeed the objective basis of the Indonesian revolution. As President Sukarno said: "It will not be an Indonesian revolution if there is no Nasakom."

Question: What do you think of the suppression or arrests of communists by the army?

Njoto: In Japan and also in South Korea, in Australia as well as Indonesia, suppressions and arrests of communists are always part of an antidemocracy policy. Concerning Japan, what I mean is not the anti-Comintern pact of former times, but during the time of MacArthur during the 1950's. Regarding Indonesia, this is not just the first time the PKI has become the target of mass oppression and arrests. We experienced them during the Dutch colonial time in 1926, then in 1936, and we experienced them yet again under Hatta's government, in 1948, and under Sukiman's Masjumi government in 1951. Each time, we rose again, and became bigger than before because, as Bung Karno said, a revolutionary movement is an objective thing which cannot be "made" by the revolutionaries, just as it cannot be curbed by the counterrevolutionaries; it will advance if not suppressed, but it will also advance even if suppressed.

Question: How about the anticommunist or anti-Chinese demonstrations of the rightwing who sometimes carried out burnings? Do you think some parts of the religious parties are rightwing?

Njoto: Both anticommunism and anti-Chinese demonstrations are directly opposed to the republic's state policy as stated in the Manipol. Regarding burnings of offices, houses, shops and so on--which are alwavs done by the rightwing and never by the leftwing--President Sukarno announced that the ones doing such things can be shot. In the religious parties, there are rightwingers and groups that represent the policy or are related with former members of Masjumi or formerly of the DI-TII. But the mass members of those parties are ordinary peasants and workers, and the interests of these are the same as the interests of the mass members of the nonreligious parties.

* One or two words are obscured in the text. 
Question: What do you think about disregard by the army, religious parties, or rightwing organizations of such presidential orders as the prohibition of demonstrations?

Njoto: Indeed, truly, the President's commands--not only his commands concerning the ban of demonstrations--are being upset by the rightwing, civilian as well as military. But the majority of the masses support President Sukarno's commands. These actions to upset the President's commands are the reason why a "committee for safeguarding the President's messages" has been set up, organized by the PPMI--the Federation of the Students' Mass Organizations of Indonesia.

Question: Who are the real powers in Indonesia?

Njoto: The Indonesian Constitution spells out that President Sukarno in addition to being head of state is also supreme commander of the ABRI and prime minister, too. The powers of President Sukarno, in combination with the forces of the people, shall determine Indonesia's fate and future.

Question: What do you think about the reshuffle of the Sukarno cabinet in the near future which the parties are now urging?

Njoto: Sooner or later, a Nasakom cabinet will be established in Indonesia. This is the wish of President Sukarno; it is the wish of the people. If President Sukarno takes this way, not only the PKI but the whole people will welcome it with joy.

Question: How about your party's course in the countryside in the future? How does your party set up liberated areas in the countryside?

Njoto: The line of the PKI in the villages is the same: support implementation of the UUPA (land reform law) and UUPBH (law concerning the dividing of crops), up till the time that the principle of "land for the tiliers of the land" and the principle of "peasants who work the land get land" can be implemented. The PKI's program is to divide the land as the individual property of each peasant, which means that a bigger family gets more. In Indonesia there is only one kind of power, the power of the Republic of Indonesia, and there is not any sort of "liberated areas."

Question: How can your party set up your own army? Lenin and Mao T'se-tung have maintained that the establishment of the army of the communist party is an indispensable condition of revolution.

Njoto: The PKI always regards the Indonesian army as being not the same as armies in the imperialist countries or as in India now, seen both from the history of its formation as well as from the tasks of being, against imperialism and feudalism, and also 
seen from the composition of its soldiers which mostly come from the peasant and worker classes. That there still exist in the national army antipeople elements is the same thing as in the republic as a whole. This is the reason for the Manipol to talk about retooling the right elements from the state bodies. But there are times when people forget this line of the Manipol and carry out retooling of the leftwing.

Question: How about the relations between your own army and the present professional army?

Njoto: The PKI has never had its own army. This is why there is no connection in any way between this thing that never existed and the national army.

Question: What do you think about the tone of Soviet arguments which regard the 30 September Movement as a rebel movement or regard General Nasution as the representative of your country along with President Sukarno?

Njoto: I only read the long article in PRAVDA on 26 November which as well as other things told of the great role played by the PKI in the national independence movement and of it being not right to oppress this party, unless you want to oppress the whole revolutionary movement. The tone of the article was defending the PKI's right to live and this is why I think it is good. The PKI only knows one head of state, supreme commander, great leader of the revolution, namely, President Sukarno, and knows no other.

Question: What do you think about the foreign reports or information about the new communist party whose policy will be peaceful coexistence such as in the Soviet Communist Party?

Njoto: It is not possible in Indonesia to establish another communist party except the PKI, unless persons want to force and bring about the forming of a party of crypto-communism or pseudo-communism. About "peaceful coexistence," this is not the foreign policy line of the republic. Not only the communists oppose this line, but also every Manipolist in Indonesia. The correct PKI and republic's foreign policy line is aimed at building a new world where no imperialism exists. Consequently the foreign policy is anti-Nekolim, and making confrontation of the Nefo against oldefo, for building a new world without imperialism.

Question: How does your party plan to avoid a civil war?

Njoto: It is true that the PKI is trying as much as possible to prevent a civil war in Indonesia. Although some are trying to misinterpret the 5 October statement of the Politburo of the Central Committee of the PKI, five days after the 30 september affair, it is nevertheless undeniable that the attitude of that 
statement is a serious attempt to prevent civil war. If murders in fact and other acts of violence happen, this is not the responsibility of the PKI, they are fully the responsibility of the ones who go against the commands of President Sukarno. But if the PKI continues to be acted against injustly then, of course, it will have the right to defend itself. 
1. General Statement by the Central Leadership Council of the Indonesian Nationalist Party. Issued on October 1. Two versions exist of the statement issued on October 1, 1965 , by the Central Leadership Council of the Indonesian Nationalist Party (D.P.P.-P.N.I.). The first can be found in the Antara news bulletin of the morning of October 2; the second appears in the Medan P.N.I. newspaper Patriot, on October 6. Since both the wording and the timing of the two versions differ significantly (Version 1 is supposed to have been issued on the evening of October 1 - i.e. after the Army counter-coup; Version 2 is reported to have been issued on the afternoon of October 1 , when the September 30 th Movement still maintained control of central Djakarta), a certain controversy has arisen over the real attitude of the P.N.I. during the critical hours of october 1. For details of this controversy, the reader is referred to Api, October 10-14, and Marhaen (Makassar), October 13, and Nasional (Jogjakarta), November 5. To allow the reader to reach his own conclusions about this point, we have included the Indonesian texts of both versions, also giving an English translation of the Antara version which the P.N.I. seems to prefer at the moment. This translation is based on the Indonesian text appearing in Antara, October 2 (Morning Edition).]

A session of the Central Leadership Council of the P.N.I., enlarged to include the leadership of the Marhaenist Mass Movement, after studying the latest developments in the capital, has taken the following decisions:

1. To remain firm and loyal to the Great Leader of the Revolution/Father of Marhaenism Bung Karno and be ready to carry out every command issued by the Great Leader of the Revolution/Father of Marhaenism Bung Karno to safeguard the revolution.

2. To acknowledge only Bung Karno's leadership of the revolution and those bodies recognized as faithful, loyal and obedient to the command of Bung Karno as the voice of the Marhaenist masses.

3. To express deep appreciation to soldiers [para pradjurit] who have shown their loyalty in safeguarding the Great Leader of the Revolution/Father of Marhaenism Bung Karno.

4. In this connection the entire membership of the P.N.I.l Marhaenist Front, within the structure of regional councils, district and branch groups, together with all members of the Marhaenist Mass Movement, declare themselves in a state of preparedness to take revolutionary actions together with other progressive revolutionary forces, under the leadership of Bung Karno, to safeguard the course of the revolution. 
5. To support every action taken to purge the apparatus of the revolution of bogus elements and those who would undermine the authority of the Great Leader of the Revolution/Father of Marhaenism Bung Karno.

6. To instruct all members of the P.N.I./Marhaenist Front to be vigilant towards the provocations of the henchmen of Nekolim and counter-revolutionary elements.

Such is the announcement of the D.P.P.-P.N.I., issued Friday night [Djum'at malam] by the Department of Information and Propaganda of the D.P.P.-P.N.I.

\section{D.P.P. - P.N.I. TENTANG PERKEMBANGAN TERACHIR DI IBUKOTA}

[This is the version contained in Antara (Warta Berita) for the morning of October 2 , 1965.]

Sidang D.P.P. - P.N.I. jang diperluas dengan pimpinan Gerakan Massa Marhaenis, setelah mempeladjari perkembangan terachir diibukota telah mengambil keputusan sbb:

1. Tetap teguh dan setia kepada Pemimpin Besar Revolusi/ Bapak Marhaenisme Bung Karno dan siap sedia mendjalankan setiap komando jang dikeluarkan oleh Pemimpin Besar Revolusi/Bapak Marhaenisme Bung Karno dalam menjelamatkan revolusi.

2. Hanja mengakui kepemimpinan revolusi Bung Karno dan badan2 jang disetudjui, setia, taat dan mematuhi komando Bung Karno sebagai penjambung lidah Massa Marhaen.

3. Menjatakan penghargaan jang tinggi kepada para Pradjurit jang telah menundjukkan kesetiaannja untuk menjelamatkan Pemimpin Besar Revolusi/Bapak Marhaenisme Bung Karno.

4. Dalam hubungan ini segenap anggota P.N.I./F.M. dalam formasi dewan daerah, tjabang sampai keranting2, beserta segenap anggota gerakan massa Marhaen, menjatakan dalam keadaan siapsiaga untuk ber-sama2 kekuatan progresif revolusioner lainnja melakukan aksi2 revolusioner dibawah pimpinan Bung Karno untuk mengamankan djalannja revolusi.

5. Mendukung setiap tindakan jang dilakukan untuk membersihkan aparatur revolusi dari kaum gadungan dan perongrong kewibawaan Pemimpin Besar Revolusi/Bapak Marhaenisme Bung Karno.

6. Menginstruksikan kepada segenap anggota P.N.I./F.M. untuk waspada terhadap provokasi2 kakitangan Nekolim dan kaum kontra-revolusioner.

Demikian pengumuman D.P.P. - P.N.I. jang dikeluarkan Djum'at malam oleh Departemen Penerangan/Propaganda D.P.P. P.N.I. 


\section{D.P.P. - P.N.I. TENTANG PERKEMBANGAN TERACHIR DI IBUKOTA}

[This is the version contained in the Medan P.N.I. newspaper Patriot, on October 6.]

Pernjataan jang diumumkan di Djakarta pada tanggal 1 October, 1965, sore, oleh Dep. Penprop D.P.P. - P.N.I. itu selengkapnja adalah sbb:

Sidang D.P.P. - P.N.I. jang diperluas dengan pimpinan Gerakan Massa Marhaen jang berlangsung di Djakarta hari Djum'at, tanggal 1 October, 1965, setelah mempeladjari perkembangan terachir diibukota telah mengambil keputusan sbb:

1. Tetap teguh dan setia kepada Pemimpin Besar Revolusil Bapak Marhaenisme Bung Karno dan siap sedia melaksanakan setiap komando jang dikeluarkan oleh Pemimpin Besar Revolusi/Bapak Marhaenisme Bung Karno untuk menjelamatkan revolusi.

2. Hanja mengakui kepemimpinan revolusi Bung Karno dan badan2 jang direstui, setia, taat dan mematuhi komando Bung Karno penjambung lidah massa Marhaen.

3. Menjatakan penghargaan jang tinggi kepada Pradjurit jang telah menundjukkan kesetiaannja untuk menjelamatkan Pemimpin Besar Revolusi.

4. Dalam rangka menghadapi segala kemungkinan, maka segenap anggota P.N.I./F.M. dalam formasi Dewan Daerah, Dewan Tjabang sampai keranting2 beserta segenap anggota Gerakan Massa Marhaen dinjatakan dalam keadaan siapsiaga untuk ber-sama2 kekuatan progresif revolusioner lainnja melaksanakan aksi2 revolusioner dibawah pimpinan Bung Karno untuk mengamankan djalannja revolusi.

5. Mendukung setiap gerakan atau tindakan jang dilakukan untuk membersihkan aparatur revolusi dari kaum gadungan dan perongrongan kewibawaan Pemimpin Besar Revolusi.

6. Menginstruksikan kepada segenap anggota P.N.I./F.M. untuk tetap mempertinggi kewaspadaan menghadapi provokasi2 kakitangan Nekolim dan kaum kontra revolusi.

Demikian pernjataan D.P.P. - P.N.I. jang dikeluarkan pada tanggal 1 October, 1965. (Sulindo).

2. Statement of the Central Leadership Council of the Marhaenist Mass Movement. Presumably issued on October 1.

The translation is based on the Indonesian text contained in the Medan P.N.I. newspaper Patriot, of October 6, 1965. The document is included because according to an official P.N.I. statement of October 15, the Gerakan Massa Marhaen was never authorized to 
put out any statements whatever about the events of October 1. In that this statement appeared alongside the above cited D.P.P. - P.N.I. statement of October 1 , it is assumed that this statement, also from Djakarta, was probably issued on October 1.]

The Central Leadership Council of the Marhaenist Mass Movement, which consists of: the Union of Marhaenist Labor, Petani, Marhaenist Youth, the Indonesian Nationalist Highschool Students' Movement, the Indonesian Nationalist University Students' Movement, the Marhaenist Women's Movement, the National Cultural Institute, the Djamiatul Muslimin, the League of Indonesian Peoples' Scholars, and the Marhaenist Fishermen's Movement,

Hereby instructs all members throughout Indonesia to carry out the instructions of the D.P.P. - P.N.I./Marhaenist Front, dated October 1, 1965, with all its consequences.

The Indonesian Revolution under the leadership of His Excellency the President/Great Leader of the Revolution/Father of Marhaenism Bung Karno demands the highest sacrifices from the whole Marhaenist Mass Movement in order to safeguard the Indonesian revolution.

1. Central Leadership Council of the Union of Marhaenist Labor

2. Central Leadership Council of Petani

3. Central Leadership Council of Marhaenist Youth

4. Central Leadership Council of the Indonesian Nationalist Highschool Students' Movement

5. Central Leadership Council signed Bachtiar Salim H., signed Notosukardjo signed Zaini Mansjur of the Indonesian Nationalist University Students' Movement

6. Central Leadership Council of the Marhaenist Women's Movement

7. Central Leadership Council of the National Cultural Institute

8. Central Leadership Council of the Djamiatul Muslimin

9. Central Leadership Council of the League of Indonesian Peoples' Scholars

10. Central Leadership Council signed Rudy H. Sihombing of the Marhaenist Fishermen's Movement

signed B. Kusnohadi

signed Mrs. Sumari

signed Sitor Situmorang

signed H. Moh. Djambek

signed Drs. Soekarno

signed S. Sawarno S.H. 
3. Press Statement of the Central Leadership Council of the Indonesian Nationalist Party on the Inclusion of Some of Its Members in the Indonesian Revolution Council. Issued on the late evening of october 1. The translation is taken from the Indonesian text in the Suluh Indonesia of October 2, as it appears in a photostat printed in Berita Yudha of October 4. Another version of the same statement, appearing, in Marhaen (Makassar) on October 4 and Patriot (Medan) also on October 4, is appended below.]

\section{(a) The PNI Central Leadership Council knows Nothing}

In connection with the inclusion of the names of members of the P.N.I./Marhaenist Front in the list of members of the "Revolution Council," the D.P.P.- P.N.I. in a press statement last night asserted that the D.P.P.- P.N.I. knows nothing about and bears no responsibility for the inclusion of those names.

In addition, the members of the P.N.I. whose names were used by the "Revolution Council," namely Surachman, Zaini Mansjur, Bambang Kusnohadi, Supeni, Sumarno S.H. and A. Karim D.P:, declare that they know nothing about and bear no responsibility for the use of their names. night.

Thus the press statement issued by the D.P.P.-P.N.I. last

(b) The D.P.P.-P.N.I. knows nothing of and bears no responsibility for the inclusion of the names of members of the leadership of the P.N.I./Marhaenist Front in the list of members of the so-called Indonesian Revolution Council.

All members of the P.N.I./Marhaenist Front are urged to continue to heighten their vigilance and not to be easily ensnared by evil intrigues and intimidation on the part of the counter-revolutionaries, and only to heed and obey instructions from the D.P.P.-P.N.I./Marhaenist Front. 
VII. STATEMENT OF THE N.U., P.S.I.I., I.P.K.I. AND CATHOLIC PARTY

1. Statement of October 4 by the Action Unit for Crushing the Counter-Revolutionary September 30th Movement. This statement of the Kesatuan Aksi Mengganjang Gerakan Kontra Revolusi 30 September, representing affiliates of the NU, IPKI, Catholic Party, and PSII, and other organizations belonging to the Joint Secretariat of the National Front, was read at a demonstration in Djakarta on October 4, 1965, by NU Vice Chairman Subhan, and presented to the KOSTRAD (Army Strategic Command) with an appeal for action. The translation is based on the Indonesian text to be found in Berita Yudha of October 5. The statement is the first public anti-Communist reaction to the events of october 1.]

The Action Unit for the Crushing of the "Counter-Revolutionary September 30 Movement", after having studied the counter-revolutionary adventure of the so-called "September 30 Movement", which has carried out counter-revolutionary actions to overthrow the legitimate government under the leadership of H.E. President/Commander in Chief of the Armed Forces/Great Leader of the Revolution Bung Karno, hereby declares with firm unanimity the following:

I. That we continue to stand completely and unreservedly behind H.E. the President/Supreme Commander of the Armed Forces/ Great Leader of the Revolution Bung Karno and are prepared to assist the Government, including the Great Leader of the Revolution Bung Karno, in destroying the "Counterrevolutionary September 30 th Movement" down to its roots.

II. That we support and are ready to carry out the policy of H.E. the President/Supreme Commander of the Armed Forces/ Great Leader of the Revolution Bung Karno in destroying the "Counter-revolutionary September 30 th Movement."

III. We condemn as harshly as possible the terrorist activities of the counter-revolutionary "September 30 th Movement" gang, which has terrorized, kidnapped and brutallv murdered several senior officers of the Army.

IV. We extend our deepest condolences and sympathy for the death of several senior officers of the Army, and pray that the several [other] senior officers whose fate is still unknown may actually be safe and well.

V. We urged H.E. the President/Supreme Commander of the Armed Forces/Great Leader of the Revolution Bung Karno to:

A. Ban and dissolve those parties and mass organizations which masterminded, supported, assisted and/or sympathized with the September 30 th Movement. According to authoritative information these are: S.B.P.U. - S.O.B.S.I., the People's Youth and other political parties and mass 
organizations with the same orientation and principles, i.e. the P.K.I. and its mass organizations, as follows: C.G.M.I., B.T.I., S.O.B.S.I., Gerwani, Lekra, H.S.I., etc., as well as institutes of higher education and other educational institutes which have become hideouts for September 30 th counter-revolutionaries.

B. Ban and revoke the publishing licenses of newspapers and magazines which directly or indirectly assisted, spread and broadcast the activities of the "Counter-revolutionary September 30th Movement," including Harian Rakjat, Warta Bhakti, Bintang Timur, Kebudajaan Baru, Ekonomi Nasional, Gelora Indonesia, etc.

C. Confiscate all assets/wealth/property of these counter-revolutionary organizations and elements, and make them state property.

VI. We urge H.E. the President/Supreme Commander of the Armed Services/Great Leader of the Revolution Bung Karno to purge the Dwikora Cabinet, State Institutes, the National Front, the National News Institute Antara, the Youth Front, the P.P.M.I., the P.W.I., the M.M.I., etc., of elements involved in, supporting, assisting and/or sympathizing with the "Counter-revolutionary September 30 th Movement", as well as of elements supporting, or in sympathy with these counterrevolutionaries, and to punish them in accordance with existing revolutionary law.

VII. We are ready, in accordance with the TAKARI Message, to work with the Government and the Armed Forces in taking action against bureaucratic capitalists, corruptors, speculators and other sowers of economic confusion.

VIII. We demand action be taken in accordance with the law of the Revolution against slanders on State authorities (the Army).

Finally we express our deep gratitude to Allah, Almighty and All-Merciful, that H.E. the President/Supreme Commander of the Armed Forces/Great Leader of the Revolution Bung Karno and His Honor the Coordinating Minister for Defence and Security/Armed Forces Chief of Staff General A.H. Nasution continue to be safe and well and are under His protection.

We call upon all political parties and mass organizations which are truly Pantjasilaist and Manipolist to assist the Armed Forces in destroying the "Counter-revolutionary September 30th Movement" down to its roots, and we are ready together with the Armed Forces under the leadership of H.E. the President/Supreme Commander of the Armed Forces/Great Leader of the Revolution Bung Karno to defend and safeguard the Pantjasila State of the Proclamation of August 17, 1945, to the last drop of our blood. Action Unit for the Crushing of the "Counter-revolutionary September 30th Movement". 
The opening of page 25 should read as follows:

\begin{tabular}{|c|c|c|c|c|c|c|c|c|}
\hline \multicolumn{5}{|c|}{$\begin{array}{l}\text { Peking: } \\
\text { Slentem (nuclear theme): }\end{array}$} & $\begin{array}{l}5555 \\
{[5]}\end{array}$ & $\begin{array}{l}6666 \\
{[6]}\end{array}$ & $\begin{array}{l}7777 \\
{[7]}\end{array}$ & $\begin{array}{l}N \\
6666 \\
{[6]}\end{array}$ \\
\hline si. & $\begin{array}{l}6656 \\
{[5]}\end{array}$ & $\begin{array}{l}5555 \\
{[4]}\end{array}$ & $[].]^{5555}$ & $\begin{array}{l}k \\
2222 \\
{[2]}\end{array}$ & $\begin{array}{l}3355 \\
{[4]}\end{array}$ & $\begin{array}{l}6666 \\
{[5]}\end{array}$ & {$\left[\frac{5533}{42}\right]$} & $\begin{array}{l}2222 \\
{[1]}\end{array}$ \\
\hline si. & $\begin{array}{l}6653 \\
{[4]}\end{array}$ & $\begin{array}{c}1223 \\
{[1]}\end{array}$ & {$\left[\begin{array}{c}2223 \\
{[.]}\end{array}\right.$} & $\begin{array}{l}K \\
2222 \\
{[2]}\end{array}$ & $\begin{array}{l}3355 \\
{[4]}\end{array}$ & $\begin{array}{l}6666 \\
{[5]}\end{array}$ & $\begin{array}{l}6755 \\
{[6]}\end{array}$ & $\begin{array}{c}6655 \\
{[5]}\end{array}$ \\
\hline Pi. & $\begin{array}{l}6666 \\
{[.]}\end{array}$ & $\begin{array}{l}6666 \\
{[.]}\end{array}$ & $\begin{array}{l}6666 \\
{[5]}\end{array}$ & $\begin{array}{l}K \\
6656 \\
{[.]}\end{array}$ & $\begin{array}{l}* \\
5655 \\
{[5]}\end{array}$ & $\begin{array}{l}5555 \\
{[5]}\end{array}$ & {$\left[\begin{array}{l}6656 \\
{[.]}\end{array}\right.$} & {$\left[\begin{array}{l}5555 \\
{[.]}\end{array}\right.$} \\
\hline si. & $\begin{array}{c}6666 \\
{[6]}\end{array}$ & $\begin{array}{l}7777 \\
{[7]}\end{array}$ & ${ }_{[2]}^{2222}$ & $\begin{array}{l}K \\
7777 \\
{[7]}\end{array}$ & $\begin{array}{l}6666 \\
{[6]}\end{array}$ & $\begin{array}{l}5555 \\
{[5]}\end{array}$ & $\begin{array}{c}3333 \\
{[3]}\end{array}$ & $\begin{array}{l}N+G \\
5 \\
{[5]}\end{array}$ \\
\hline
\end{tabular}

* At this point the peking resumes its 'normal' paraphrase.

On page 25, line 21: intentional 'errors' should read 'intentional errors.'

On page 28 , lines $35-36$ should read:

$$
\begin{array}{llllllllllllllllll} 
& K & & & K & & & & K & & & & K & & N \\
\text { [21.] } & 3 & 3 & 6 & 5 & 3 & 2 & 6 & 6 & 5 & 6 & 5 & 4 & 2 & 4
\end{array}
$$

On page 29, line 47 should read: During the kraton rehearsal hours on Wednesday nights, he generally plays....

On page 29 at the bottom of the page there should be added the following:

(e) The greatest discrepancy between the manuscript and the recorded version lies in the time-duration. Whereas the manuscript specifies an optimum duration of $20^{\prime} 00^{\prime \prime}$, the recorded performance, even with incomplete repetition, lasts $2^{\prime} 00^{\prime \prime}$.

[The author wishes to express his sincerest thanks to Mr. N. Tirtaamidjaja (Djakarta), who graciously provided all the factual information used in this note, and to $\mathrm{Mr} . \mathrm{B}$. Anderson (Ithaca), who removed the many Dutch idiosyncracies in the original English copy.] 